\title{
GENITAL MORPHOLOGY DIFFERENTIATES THREE SUBSPECIES OF THE TERRESTRIAL SLUG ARION ATER (LINNÆUS, 1758) S.L. AND REVEALS A CONTINUUM OF INTERMEDIATES WITH THE INVASIVE A. VULGARIS MOQUIN-TANDON, 1855
}

\author{
Heike Reise*, ANNe-Katrin Schwarzer, John M. C. Hutchinson, Bettina SchlitT
}

\author{
Senckenberg Museum of Natural History Görlitz, Am Museum 1, 02826 Görlitz, Germany \\ (e-mail: heike.reise@senckenberg.de, anne.k.schwarzer@gmail.com, majmch@gmail.com \& \\ john.hutchinson@senckenberg.de, bettina.schlitt@senckenberg.de); \\ JMCH 구 https://orcid.org/0000-0003-3166-3045 \\ *corresponding author
}

\begin{abstract}
The terrestrial slug Arion vulgaris Moquin-Tandon (= A. lusitanicus auct. non Mabille) is an important agricultural pest that has invaded much of Europe. Previous work has demonstrated hybridisation with $A$. ater (Linnæus) s.l. We describe the genital anatomy of morphological intermediates found in eastern Saxony (Germany), comparing them with the parent species. We recommend a standard method of genital dissection and consider a set of five genital characters. The intermediates demonstrate the homology of the ligula-bearing organs of the two species; the ancestral position of the ligula in the dilated part of the oviduct has moved to the upper atrium in A. ater s.l. Furthermore we differentiate three morphotypes of A. ater s.l. in eastern Saxony, associated with different mitochondrial DNA sequences. One is A. ater ater, previously unrecognised from this part of Germany and the Czech Republic. The two other morphotypes correspond to the predominantly British and the Continental subspecies previously recognised on genetic and morphological grounds. We designate as the lectotype of Limax rufus Linnæus, 1758 a non-surviving specimen from Almondbury, England, described by Lister; thus the predominantly British subspecies becomes A. ater rufus. The appropriate name for the Continental form is A. ater ruber (Garsault, 1764).
\end{abstract}

KEY WORD: Arion ater ruber, Arion lusitanicus, Arion rufus, Spanish slug, Pulmonata, Arionidae, COI, hybrid, lectotype, ligula, Martin Lister, pest slug

\section{INTRODUCTION}

The group of large slugs of the genus Arion has been a notoriously difficult taxonomic puzzle (e.g. NOBLE 1992, NOBLE \& JONES 1996, QUINTEIRO et al. 2005, Rowson et al. 2014a): even for the comparatively well-studied area of Central and North-West Europe different opinions persist about the number and nomenclature of species or subspecies. The situation gets more complex when considering slugs from South-West Europe, the group's region of highest diversity. There are several reasons for the confusion. (1) External morphology (mainly body colour), on which early original descriptions were based, is only locally reliable for the distinction of taxa within the group and may fail even to distinguish them from other groups of Arion. (2) Type specimens or welldefined type localities are not available to settle at least the nomenclatural disagreements. (3) The interand intrapopulation diversity in genital morphology seems rather large, making taxonomic interpretation of morphological differences difficult. This might partly be related to the next two issues, (4) ongoing human-mediated introductions across Europe and (5) potential interbreeding between some or all taxa at contact zones of various ages. 


\section{TAXONOMIC BACKGROUND}

The first large Arion species to be described were the Northern European A. ater s.s. and the more Central and Western European A. rufus (e.g. QUicK 1947, CHEVALLIER 1972, 1981). Originally described as, respectively, the "black" and the "red" slug by LINNÆUS (1758), they were considered as one species (A. empiricorum: e.g. FÉRUSSAC 1819-1851, SimROTH 1885; A. rufus: e.g. MOQUIN-TANDON 1855; A. ater s.l.: e.g. FLEMING 1822, TAYLOR 1902-1907, PILSBRY 1948) when body colour was recognised as not taxonomically relevant but were separated as species again when genital and behavioural differences were recognised (POLLONERA 1890, GERHARDT 1940, QUICK 1947, BOETTGER 1949a). However, the recognition of morphological intermediates at sites of sympatry in the British Isles, interpreted as indications of interbreeding, led British authors to change the status from species to subspecies (e.g. CAIN \& WILLIAMSON 1958, QUICK 1960, EVANS 1986, NOBLE 1992) or forms (KERNEY 1999). Most recently, ANDERSON (2005) and RowsOn et al. (2014a, b) returned to considering them as separate species. Continental authors, on the other hand, have tended consistently to consider the two taxa as separate species (e.g. JAECKEL 1962, ZILCH 1962, WIKTOR 1973, CHEVALLIER 1974), but there was uncertainty about whether A. ater s.s. really occurs in Central Europe or whether such records were based just on black individuals of A. rufus (GERHARDT 1940, BOETTGER 1949a, b).

The name $A$. empiricorum was introduced by FÉRUSSAC (1819: 60) for the same group of big Arion; he included Linnæus's black and red slugs as two colour morphs amongst others from the whole of Europe. The name has then been applied to all European large Arion outside the Iberian Peninsula (partly excluding whitish individuals) (e.g. SIMROTH 1885, Hesse 1926, CheVAllier 1972), to A. ater s.s. and $A$. rufus together (e.g. EHRMANN 1933), to all A. rufus-like slugs (e.g. POLLONERA 1890, GERHARDT 1940), to a form of A. rufus occurring on the British Isles and continental Europe (COLLINGE 1897a, b), and to Continental A. rufus alone (ANDERSON 2005, ROWSON et al. 2014a). However, QUICK (1947), BOETTGER (1949b), and VAN REgTEREN ALtenA (1963) stressed that the name A. rufus has priority over A. empiricorum. Even if we consider $A$. ater s.s. as distinct, there is still the question whether $A$. rufus in Central and Western Europe consists of a single species or of two or more distinct taxa; the latter has been indicated by morphological (COLLINGE 1897a, b, CHevallier 1972, 1974) and genetic (RowsON et al. 2014a) studies.

The other large Arion occurring in Central Europe is A. vulgaris Moquin-Tandon, 1855. This common pest slug has also been called A. lusitanicus or, after it turned out not to be identical with the true $A$. lusitanicus Mabille, 1868 from Portugal (CASTILlejo 1998, QUINTEIRO et al. 2005), A. lusitanicus auct. non Mabille, 1868 . The name $A$. vulgaris was originally intended for a colour morph of an "A. rufus" commonly found in France, and the type locality is no more precise than "France". However, the name has been increasingly used for the pest slug, and BALASHOV (2018) and KADOLSKY et al. (2018) have now applied to the ICZN to make A. vulgaris the valid name, which is why we will use it here. Arion vulgaris was included with $A$. rufus and $A$. ater s.s. in CHEVALIER's (1972) A. empiricorum group and ColLINGE's (1897b) A. ater group.

\section{THE INVASION OF ARION VULGARIS}

Arion vulgaris, now widespread in synanthropic habitats of Central and Western Europe, started to attract attention as a significant pest $50-60$ years ago. PFENNINGER et al. (2014) postulated that the slug is native to Central Europe, but another genetic study based on more extensive sampling and additional microsatellite DNA markers (ZEMANOVA et al. 2016) has convincingly indicated an origin somewhere in Western France. A number of studies have examined its spread northwards and eastwards across Europe, its biology, its effect on the native flora and fauna, and the reasons for its success (e.g. VON PROSCHWITZ 1996, 1997, GRIMM 2001, AGUIAR \& WINK 2005, KOZŁOWSKI 2007, KNOP \& REUSSER 2012, SLOTSBO et al. 2011a, b, 2012, KAPPES et al. 2012, JENSEN et al. 2013, ZEMANOVA et al. 2017). Considered as one of the 100 worst invasive pest species (RABITSCH 2006), it continues to spread, currently expanding its range northwards in Scandinavia and eastwards in Eastern Europe (HATTELAND et al. 2013, PĂPUREANU et al. 2014, and references therein). There is now also a genetically confirmed record from North America (ZEMANOVA et al. 2018). Wherever it appeared, populations reached very high densities within a few years and cause considerable damage to horticultural and agricultural crops (e.g. CHEVALLIER 1972, REISCHÜTZ 1984, VON PROSCHWITZ 1996, 1997, FISCHER \& REISCHÜTZ 1998, DVOŘÁK \& HORSÁK 2003, KozŁOWSKI 2007, KOZŁOWSKI \& KOZŁOWSKI 2011), although Britain might be an exception (DAVIES 1987).

Arion vulgaris has been reported to cause local extinction of the native $A$. rufus (REISCHÜTZ \& SEIDL 1982, DE WiNTER 1989, KAPPES \& KOBIALKA 2009, RÜETSCHI et al. 2012, DreIJERS et al. 2013) or, in Northern Europe, A. ater s.s. (VON PrOsCHWITZ 1996, 1997, ROTH et al. 2012, HATTELAND et al. 2015, HAGNELl et al. 2004). Possible reasons for this superiority of the invasive species are higher survival 
(RYSER et al. 2011) and a better ability to exploit new resources (KAPPES et al. 2012, BLATTMANN et al. 2013). Very probably the disappearance of the native species is related also to hybridisation (RHYMER \& SIMBERLOFF 1996). Matings of $A$. vulgaris with $A$. rufus or with supposed $A$. rufus $\times$ ater hybrids have been observed (ROTH et al. 2012, DREIJERS et al. 2013, ALLGAIER 2014), and HATTELAND et al. (2015) reported from an invaded Norwegian population of A. ater s.s. a few wild collected individuals that were morphologically classified as one species but had COI and/or ITS sequences typical of the other. The strongest evidence comes from transect studies in the Swiss mountains (ZEMANOVA et al. 2018) using microsatellites and mitochondrial DNA; the results indicate that hybridisation at the contact zones, including backcrosses in both directions, was not uncommon.

Another strand of evidence is morphological intermediates in populations of $A$. ater s.s. or A. rufus where $A$. vulgaris has invaded (FALKNER 1981, HAGNELL et al. 2004, ENGELKE et al. 2011, ZEMANOVA et al. 2018). However, further details about those supposed hybrids are sparse. They are crudely described as intermediate, untypical, or highly variable, but a detailed, systematic description of their genital morphology has been lacking. The risk is that everything untypical might be considered as a potential hybrid. Confounding the issue is the interbreeding of $A$. rufus and $A$. ater s.s. where these co-occur (CAIN \& Williamson 1958, NOBLE 1992, ROTH et al. 2012, HATTELAND et al. 2015). The original scope of this study was to report intermediates from a study area in eastern Germany where A. vulgaris was invading and to describe their genital morphology thoroughly.

Arion vulgaris was found in the town of Görlitz in 1994, its first known occurrence in eastern Saxony,

\section{MATERIAL AND METHODS}

\section{SPECIMENS}

For the search for morphological intermediates between $A$. ater s.l. and A. vulgaris, we have screened c. 3,500 individuals collected in Görlitz and its neighbourhood. All of the 2,055 specimens collected at the monitoring sites were investigated anatomically. The others were from 529 samples collected sporadically between 1966 and 2014 but with a particular focus on the immigration of $A$. vulgaris since 1994. Of these, at least one individual per sample, but usually several, were dissected.

To give an overview, we found 77 specimens intermediate between $A$. ater s.l. and A. vulgaris amongst the slugs from the monitoring sites and a similar
Germany (REISE et al. 1996). We have followed its subsequent spread in the area, with some monitoring sites sampled repeatedly; details will be published elsewhere. Shortly after the arrival of $A$. vulgaris, morphological intermediates were found for the first time at many localities in Görlitz and its surroundings. Simultaneously, the established synanthropic populations of $A$. rufus decreased and have now largely disappeared.

Besides individuals that appeared to be truly intermediate morphotypes, many individuals had some intermediate characters but tended towards one or the other of the supposed parental species. To separate these from the parental species, we had to define more precisely the morphology of "pure" $A$. rufus and $A$. vulgaris. For $A$. rufus, we used material collected before the arrival of $A$. vulgaris. Initially we had difficulties defining the typical morphology of $A$. rufus because it was so variable. As a consequence, we have broadened the study to include a description of the variability of $A$. rufus in the study area, utilising additional morphological characters and partial-COI mtDNA sequences. We think that we can identify three different morphotypes of " $A$. rufus", which we find also in samples from elsewhere in Europe, and which correlate with genetic differences. We will conclude that one of these morphotypes corresponds to $A$. ater s.s., occurring well to the south of the assumed range, and that the two other morphotypes of $A$. rufus occurring in the region should be considered as subspecies. Thus this study has a broad significance for the taxonomy of $A$. ater s.l. In what follows, we will use "A. ater s.l." to refer to $A$. ater s.s. and the two morphotypes of $A$. rufus. At the end of the Discussion we resolve the nomenclatural issues more formally.

number amongst the other slugs from the neighbourhood of Görlitz. All intermediate slugs from the monitoring sites and a selection of 51 other intermediates were classified into three different morphological classes (see Results).

For reference specimens of $A$. ater s.l. and A. vulgaris we selected populations around Görlitz so as to minimise the risk of recent hybridisation. This was straightforward for $A$. ater s.l. because we could use populations from sites where $A$. vulgaris had not yet arrived at the time of collection. These were specimens in the collection of the Senckenberg Museum of Natural History Görlitz (SMNG) collected in Görlitz and surroundings between 1966 and 1996 (locally up to 1998; c. 150 specimens) as well 
as slugs from the Polish sister town Zgorzelec and from the village of Pisarzowice in Poland, $16 \mathrm{~km}$ east of Zgorzelec, collected 1994-2013 (c. 340 specimens). Reference specimens of $A$. vulgaris were taken from a well established population at the Nikolai cemetery in Görlitz between 2010 and 2012 (c. 300 specimens). At this site, the invasive species had occurred at least since 2000, and A. ater s.l. had not been found after 2004 despite repeated collections (DREIJERs et al. 2013).

We considered as morphological intermediates those individuals that did not fit into the range of intraspecific variability of the pure reference populations. Such morphological intermediates turned up at several sites in and around Görlitz, always within the first years after $A$. vulgaris had arrived at a site where A. ater s.l. occurred. Here, we have studied in greatest detail the intermediates found at the monitoring area called "Rutschung P", but the general pattern is the same elsewhere around Görlitz.

The site Rutschung P, monitored between 1994 and 2014, is an old landslide at the margin of a brown-coal opencast mine outside of the town of Görlitz. The area, originally the eastern margin of the village Jauernick-Buschbach and comprising gardens, a road and a small patch of woodland, slid down into the mining hole between 1980 and 1990 (MUDER et al. 2002) and was since largely left undisturbed. Except for the patch of woodland and some single fruit trees which continued growing, the area was initially mainly open land, but woodland developed during the period of study. Open soil, grass, or tall forbs remained only on rather dry patches and steep slopes. In the first years of the study, A. ater s.l., then the only representative of large Arion on the study area, was limited to the patch of old woodland. The first A. vulgaris turned up in 1997 at the margin above the area, and a mass occurrence on the adjacent meadows and fields about $1 \mathrm{~km}$ west of the study site was discovered in 1998. In 1999, A. vulgaris was already widespread on the open and half-open habitats of the study area. Morphological intermediates were found since 1999. Individuals anatomically identifiable as pure A. ater s.l. were no longer found after 2005.

As we only realised the existence of distinct morphotypes within $A$. ater s.l. in the course of the study, a selection of 58 specimens ( $43 \%$ of these from the monitoring sites, mainly Rutschung $\mathrm{P}$ ) of $A$. ater s.l. were reinvestigated. These were compared with specimens of A. rufus from France, Great Britain, Sweden, and eastern Poland and with specimens of $A$. ater s.s. from Sweden, Great Britain, the Faroe Islands, and Lithuania (Table 1).

Slugs collected since about 2000 were killed in carbonised water and fixed in $70 \%$ ethanol (see REISE 2013). Slugs of earlier collections were either drowned in water or killed in diluted (c. 30\%) ethanol. All specimens are stored in $70 \%$ methylated ethanol in the collection of the Senckenberg Museum of Natural History Görlitz.

\section{THE DISTAL GENITALIA AND THEIR ANATOMICAL INVESTIGATION}

For anatomical investigations, we used an Olympus SZX2-ZB10 binocular microscope. The slugs were dissected following a standard procedure (REISE 2013). They were cut open along the left foot fringe. The dorsal body wall was then lifted up, turned over to the right side, and pinned down. This procedure slightly pulls out the distal genitalia (see REISE 2013: fig. 2, ROWSON et al. 2014b). Descriptions of relative positions of genital parts refer to animals opened in this way. The distal genitalia were cut out from the rest of the body only if used for illustrations. By "distal" we mean nearer the genital pore in the retracted genitalia.

In Arion species, the genital atrium is usually divided into a glandular distal part (lower or anterior atrium) and a usually bigger and muscular proximal part (upper or posterior atrium) where the epiphallus, the duct of the bursa copulatrix and the oviduct insert (e.g. Fig. 1). No penis is present (SIMROTH 1885, NOBLE 1992, but SCHILEYKO 2007 uses a different terminology) or, under some interpretations, it is dramatically reduced (BACKELJAU \& VAN BEECK 1986). In some species of Arion, there is a big, cylindrical, muscular part between the atrium and the true oviduct (Fig. 2), called "distal oviduct", "dilated part of the oviduct" (e.g. VAN REGTEREN AltenA 1956, NoBle 1992, CASTILlejo 1997, HATTELAND et al. 2015), "proximal part of the oviduct" (RISCH \& BACKELJAU 1989), or something similar. We use "dilated oviduct" in this article. This part, like the atrium, is everted during mating.

The large Arion species have a characteristic structure, the ligula, attached to the inner wall of the dilated oviduct if this is present (as in A. vulgaris) or, otherwise, to the inner wall of the upper atrium (in A. ater s.l.). This complex structure reveals its shape best when everted during copulation, whereas at rest it is folded up in partly inconsistent ways to fit inside the atrium or dilated oviduct. Particularly in species in which the ligula is very large, it may be difficult to understand its configuration. This has hampered both the description of the morphological variability and the distinction of the variation in fundamental structure from the superficial differences partly caused by inconsistent folding. In this context it was helpful to distinguish what we term the "base" and the "flange" of the ligula. The base (called "floor" in NOBLE 1992) is the longish, roughly oval part of the ligula that lines the inner wall of 


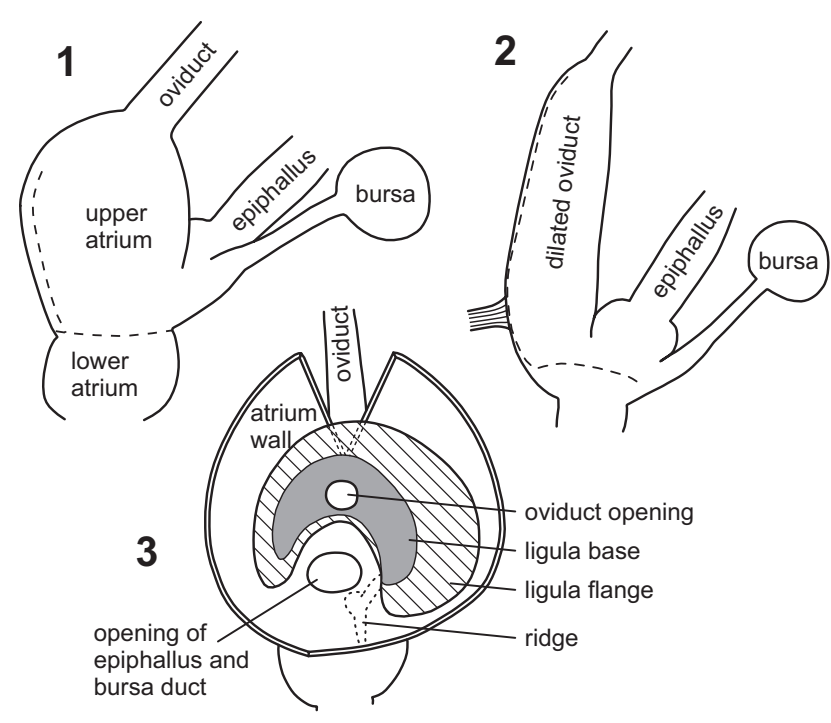

Figs 1-3. Schematic sketches of the genitalia of: $1-$ Arion ater s.1., $2-A$. vulgaris (dashed lines in 1 and 2 indicate the cuts recommended), 3 - the opened upper atrium of A. ater s.l. viewed from the inside, with the dorsal side of the atrium in Fig. 1 reflected over to the right: the cut edge is indicated with a double line

the atrium or oviduct. Attached by its edge around this base is a flap of tissue, the flange (called "wall" in NOBLE 1992). In places this flange is much broader, and sometimes also thicker, than in others, with this pattern varying between morphotypes, although also within. The position of the opening of the true (thin) oviduct into the ligula-bearing atrium or dilated oviduct varies but is always within the ligula. The general appearance of the ligula varies considerably, not only between individuals of the same or different morphotypes but also depending on where the atrium was cut open and the resulting viewpoint. It can be particularly confusing if the ligula or other important structures have been damaged, so this should be avoided. We recommend to open these genital organs as follows.

For $A$. vulgaris-like individuals (i.e. those with a dilated oviduct), first make a longitudinal cut along almost the whole length of the dilated oviduct, starting just beside the (intact) distal oviduct retractor. The cut should not continue quite up to the insertion of the thin oviduct to avoid cutting the ligula curving around its entrance. Next, open the atrium with a cut roughly perpendicular to the first, starting at the insertion of the dilated oviduct and ending distal to the insertion of epiphallus and bursa-duct (Fig. 2). The dilated oviduct and the atrium can then be opened.

For specimens without a dilated oviduct, we recommend an initial cut along the margin between upper and lower atrium for about half the circumference of the atrium (this may demand detaching the atrium retractor from the body wall) and a second cut along the atrium side opposite to the insertion of epiphallus and bursa-duct. This second cut should start from the first cut and run roughly perpendicular to it, towards the oviduct insertion. It should end at the ligula insertion on the atrium wall inside (Figs $1,3)$. This point cannot be missed as the ligula there projects a big flange into the atrium. Depending on the extent of the ligula base, this cut may reach up close to the apical end of the atrium (near the oviduct insertion) or may stop already half way up (see: Results Figs 5-7, 11-13, 16-18; the slugs depicted in Figs 25-39 have been dissected in this way).

An alternative cut is possible (and the atrium consequently opened wider) on the opposite side of the atrium, just behind the atrium retractor and very close to the epiphallus insertion (this demands detaching the retractor first). The disadvantages of this are that the flange on this side is much smaller and may possibly go unnoticed and be cut, and that the position of the ligula relative to the epiphallus and bursa-duct openings is then less obvious.

The ligula attaches to the inside of the atrium wall, but it is helpful to visualise this region of attachment as seen from the outside. Accordingly we inserted fine pins (small insect pins cut in half) through the atrium wall along the line where the flange attaches to the base. To better visualise and generalise three-dimensional genital structures, we also created models with coloured plasticine.

Most of the c. 3,500 dissected specimens were studied repeatedly, some five or more times. One of us, A-KS, examined every individual from the monitoring sites. Many specimens, including all critical specimens, were investigated by both A-KS and HR, usually repeatedly.

\section{DNA SEQUENCING}

For some specimens we sequenced the standard bar-coding region of the mitochondrial COI gene (655 base pairs). DNA extraction from foot muscle tissue, amplification, and purification followed the methods described by HUTCHINSON et al. (submitted). When the standard Folmer et al. (1994) primers failed to amplify the full sequence, other primers were often successful in amplifying sections approximately two-thirds of this length (HUTCHINSON et al., submitted). The sequencing, in both directions, was carried out by the Laborzentrum BIK-F (Frankfurt/ Main, Germany). Any sequence not found more than once was compared against the most similar sequences, and the electropherograms rechecked manually at the sites where the sequences differed.

Of the specimens from Görlitz and its neighbourhood investigated morphologically, 83 specimens yielded partial-COI sequences. These were not an unbiased sample because we were more likely to sequence specimens of intermediate or untypical mor- 


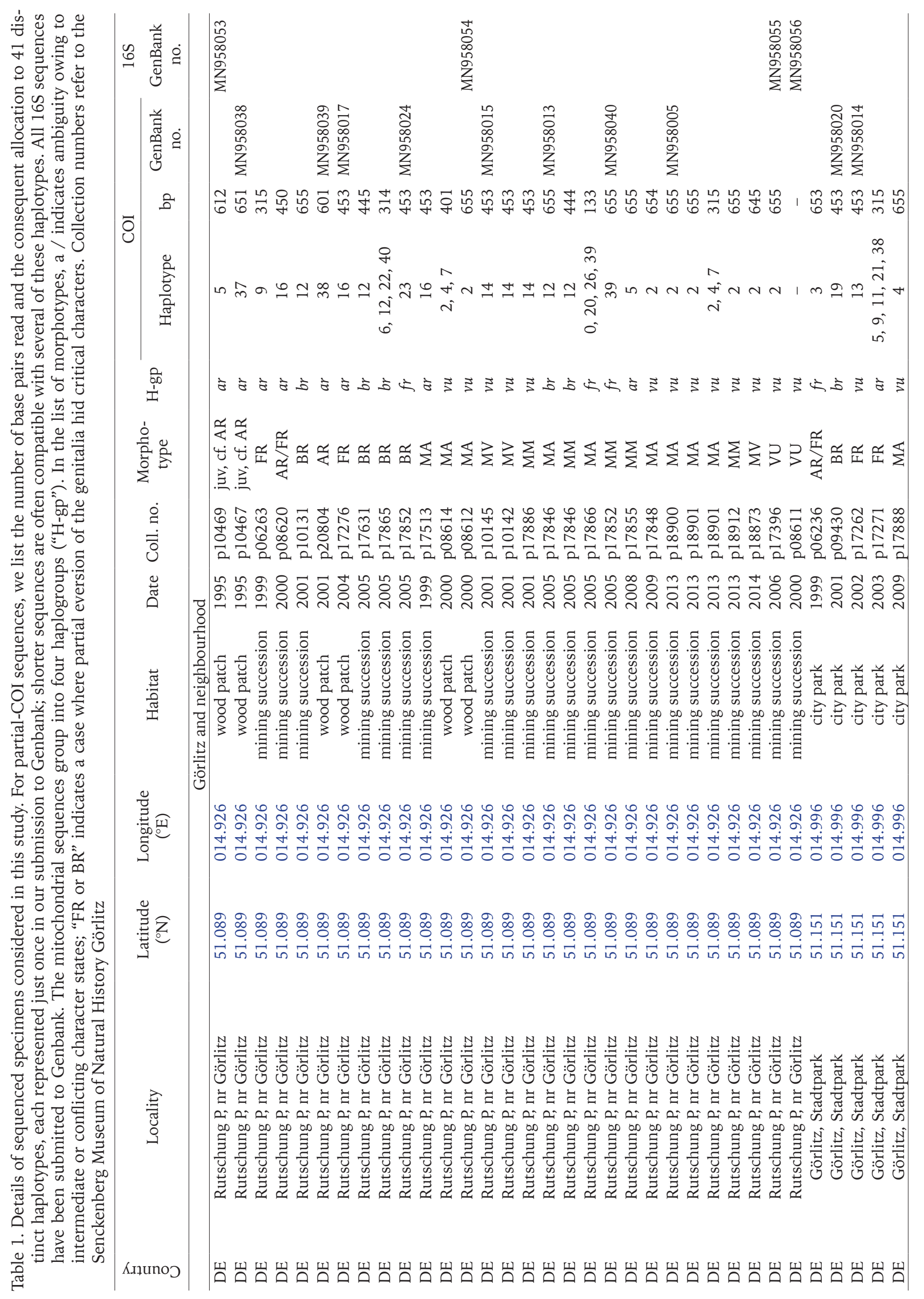




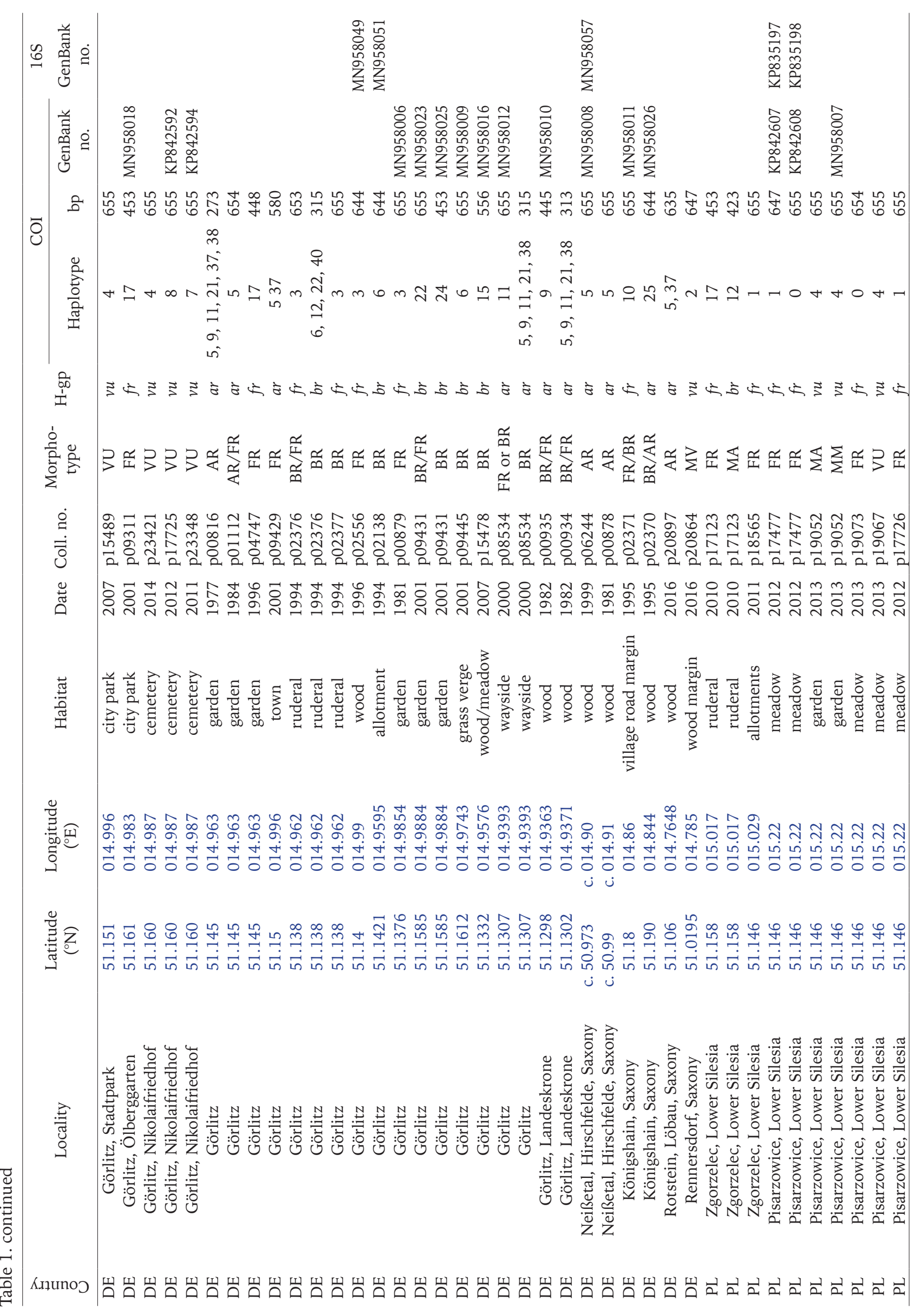




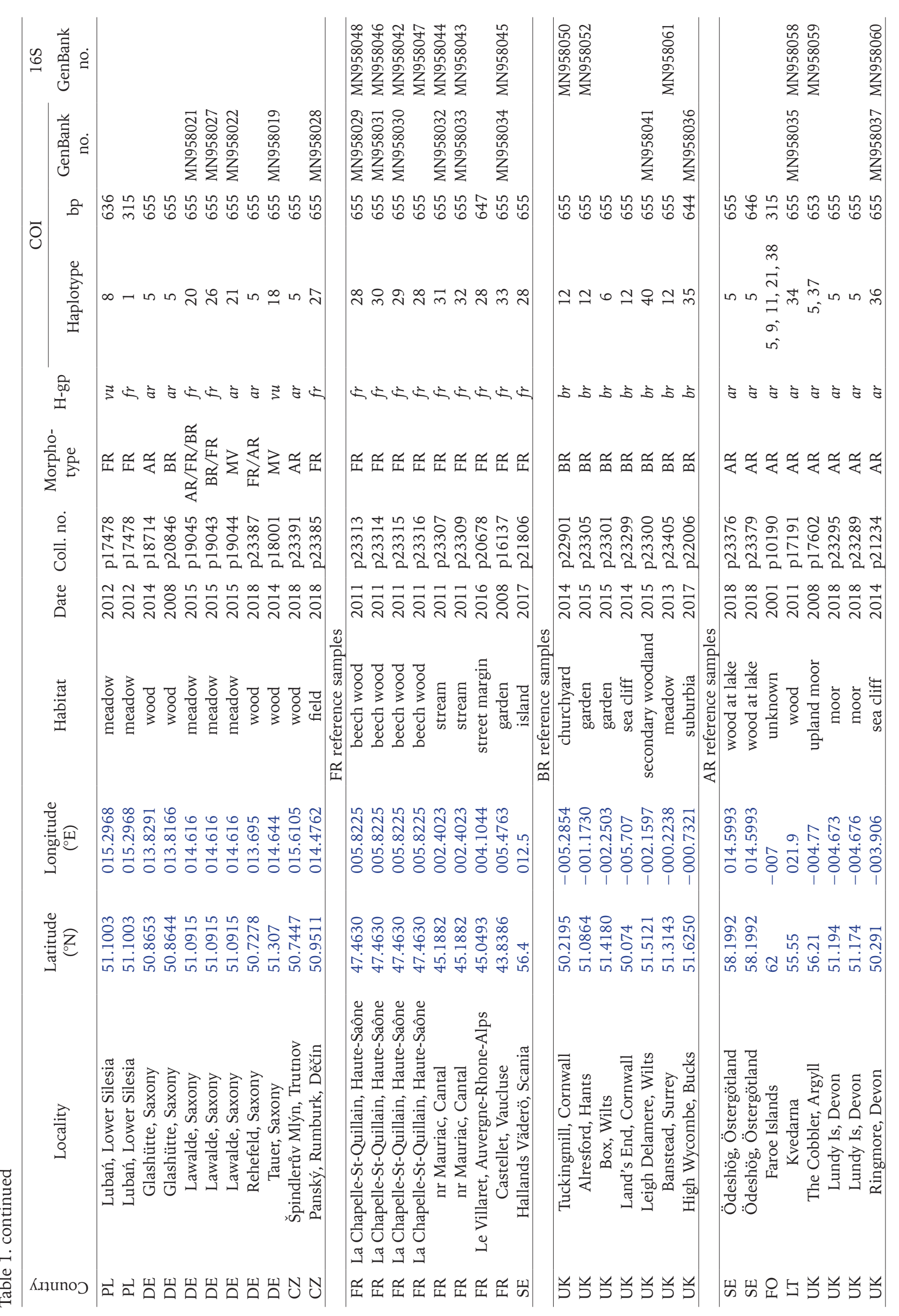


phology. We added to our genetic analysis 24 A. ater s.l. with identical or similar partial-COI sequences from elsewhere in Europe from individuals available for morphological examination (Table 1).

The sequences were grouped into a minimum set of distinct haplotypes, each represented by the most complete of the matching sequences. (Some incomplete sequences fit more than one of these haplotypes). We calculated by how many base pairs the haplotypes differed from each other, and these data were input into TCS (CLEMENT et al. 2000) so as to construct a gene network using the principle of statistical parsimony. The connection limit was set at $13(2 \%)$ corresponding to a probability of statistical parsimony of 0.94 (function .TempletonProb() in $\mathrm{R}$ package "pegas": PARADIS et al. 2018).

A subset (22) of the individuals whose COI was sequenced also had part of their 16S RNA gene sequenced. The methodology was similar as for COI, using primers 16Sar and 16Sbr (SIMON et al. 1994).

\section{RESULTS: GENETICS}

Of the 107 COI sequences obtained, 56 were full length $(655 \mathrm{bp})$, with another 11 individuals $>600$ bp and only 11 individuals $<400 \mathrm{bp}$. They could be represented by 41 distinct haplotypes, of which 31 were found in the Görlitz region. Of the 41 haplotypes, 28 included full-length sequences, another 4 included sequences $>600 \mathrm{bp}$, and all included sequences of $\geq 445 \mathrm{bp}$.
The program TCS constructed four unconnected gene networks of haplotypes (Fig. 4). Within any one network, no haplotype differed from another by more than 13 bp (2\%), whereas the minimum difference between haplotypes in different networks was $33 \mathrm{bp}$ (between haplotypes of only $453 \mathrm{bp}$; the minimum percentage difference was $5 \%$ : Table 2). Each network consisted of 20 to 32 individuals fitting 5 to 14 distinct haplotypes.

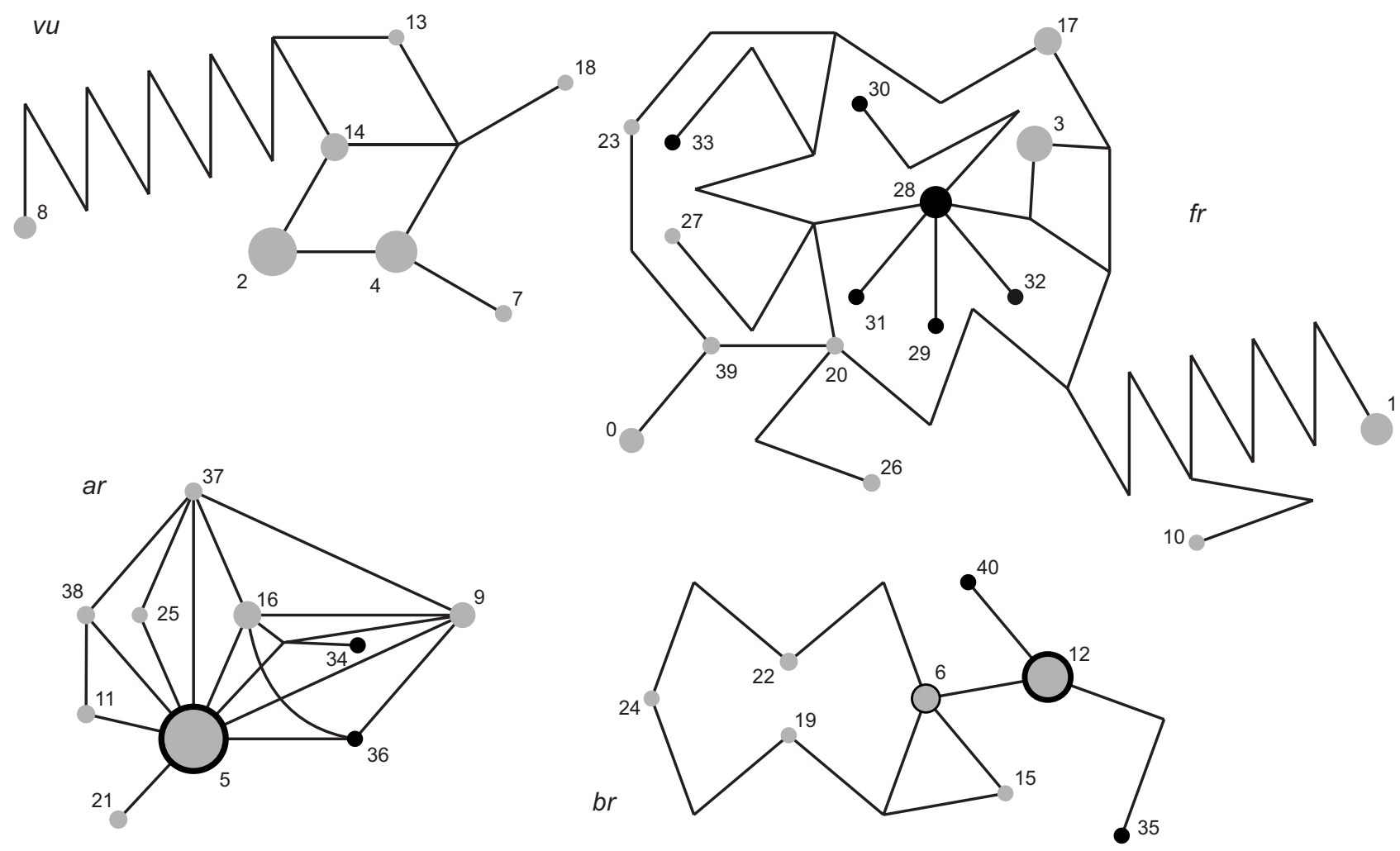

Fig. 4. Partial-COI haplotype networks of large Arion. Each straight-line segment implies a single-base mutation between observed or inferred haplotypes (at the vertices). The same applies to the curved line, which should be imagined to bridge over the lines it crosses. Numbers refer to the individual haplotypes listed in Table 1. Grey disks indicate haplotypes found in the neighbourhood of Görlitz, with the area proportional to the number of individuals (total number sequenced $=83$ ); ambiguous sequences were split amongst compatible haplotypes proportional to the number of unambiguous Görlitz individuals. Sequences found in the reference populations beyond Görlitz are indicated in black with the area of disk or annulus proportional to the number of individuals (ambiguous sequences excluded). Networks were calculated by the program TCS using a connection limit of 13 steps, yielding four unconnected networks, corresponding to the four haplogroups $v u, f r$, ar and $b r$ 
Table 2. Percentage differences between most similar members of different haplogroups based on partial-COI sequences. Maximum length was $655 \mathrm{bp}$, (so then $5 \%=$ $33 \mathrm{bp}$ ); haplotypes for which $<500$ bp were sequenced were ignored

\begin{tabular}{ccccc}
\hline & \multicolumn{4}{c}{ Haplogroup } \\
\cline { 2 - 5 } & $f r$ & $b r$ & $a r$ & $v u$ \\
\hline$f r$ & - & 5.0 & 6.9 & 7.8 \\
$b r$ & 5.0 & - & 6.8 & 7.7 \\
$a r$ & 6.9 & 6.8 & - & 6.7 \\
$v u$ & 7.8 & 7.7 & 6.7 & - \\
\hline
\end{tabular}

One of these networks (including 24 slugs from the vicinity of Görlitz) corresponds to A. vulgaris: the sequences include those that PFENNINGER et al. (2014) and ZEMANOVA et al. (2016) treated as this species, and all local individuals that were scored as morphologically $A$. vulgaris had sequences within this network. Note that, if there is introgression between $A$. vulgaris and $A$. ater s.l., we do not necessarily expect a perfect correspondence between morphology and the mitochondrial sequence. We report the details of this correspondence below, although we have sequenced only a minority of the individuals examined morphologically. We describe slugs with a partial-COI sequence within this network as part of the $v u$ haplogroup, regardless of their morphology.

To understand the significance of the other three gene networks, we searched Genbank and sequences from our own collection for identical and similar sequences from elsewhere in Europe. One network (in-

\section{RESULTS: MORPHOLOGY}

In this section we will describe first three morphotypes of $A$. ater s.l. and then A. vulgaris, emphasising morphological structures distinguishing these taxa. Finally, we will describe the morphological intermediates between $A$. ater s.l. and A. vulgaris found in the field.

We consider the following set of characters that distinguish A. ater s.l. from A. vulgaris: (1) the relative size and shape of the atrium and the dilated part of the free oviduct, (2) the positions of the openings of epiphallus and bursa-duct into the upper atrium, (3) the position, size and shape of the ligula, (4) the presence or absence of a fold structure, the posterior lip (ALLGAIER 2014), protruding from the opening of epiphallus and bursa-duct, and (5) the relative size of tubercles covering the inner wall of the distal epiphallus (just proximal to the opening into the atrium). For each morphotype, we will consider this same set of characters in the order above. cluding 25 slugs from the Görlitz area) grouped with individuals from the British Isles and Scandinavia that had been identified morphologically as A. ater s.s. (e.g. ROWSON et al. 2014a, ZEMANOVA et al. 2018); we call this the ar haplogroup. Another network (including 21 slugs from the Görlitz area) grouped with individuals widely distributed in France, the Low Countries, and Scandinavia, occurring also in Switzerland, western Germany, Poland, one site in Spain, and North America, but with a conspicuous dearth of examples from the British Isles; we call this the $f r$ haplogroup ("French rufus"). The last network (including 13 slugs from the Görlitz area) grouped with individuals mostly from Britain but also from three sites in France, two distant sites in Germany, and from Iceland; we call this the $b r$ haplogroup ("British rufus").

ROWSON et al. (2014a) observed that A. rufus sequences of another mitochondrial gene, 16S RNA, showed a similar pattern of divergence between the British Isles and the Continent. At only one British site did they find the Continental form, which they tentatively referred to as $A$. cf. empiricorum, whereas the British form (to which they restricted the name A. rufus) was found at 19 sites in the British Isles. We have sequenced the $16 \mathrm{~S}$ gene of 10 individuals with partial-COI sequences of the $f r$ haplogroup and 4 individuals of the br COI haplogroup (see Table 1). As expected, the $16 \mathrm{~S}$ sequences of these two haplogroups were similar to those from RowsON et al.'s (2014a) A. cf. empiricorum and A. rufus respectively.

\section{GENERAL MORPHOLOGY OF A. ATER S.L.}

We were surprised that slugs from the neighbourhood of Görlitz identified morphologically as A. ater s.l. had four different sorts of COI sequence: besides two morphological $A$. rufus with a COI sequence typical of $A$. vulgaris, also the $a r, f r$, and $b r$ haplogroups. This stimulated us to examine whether the three $A$. ater s.l. haplogroups differed morphologically. Indeed, we think that we can distinguish such morphotypes. We refer to these using capital letters AR, BR, and FR corresponding to the COI haplogroups $a r, b r$, and $f r$. However, as with A. vulgaris, any correspondence is liable to be disrupted by hybridisation and introgression. Therefore we investigated the morphology of slugs from the heartlands of where these haplogroups occurred elsewhere in Europe and then examined whether the same differences in morphotype could be recognised in material from the neighbourhood of Görlitz. In our study area, we did find all three $A$. ater s.l. morphotypes. But we also found individuals 

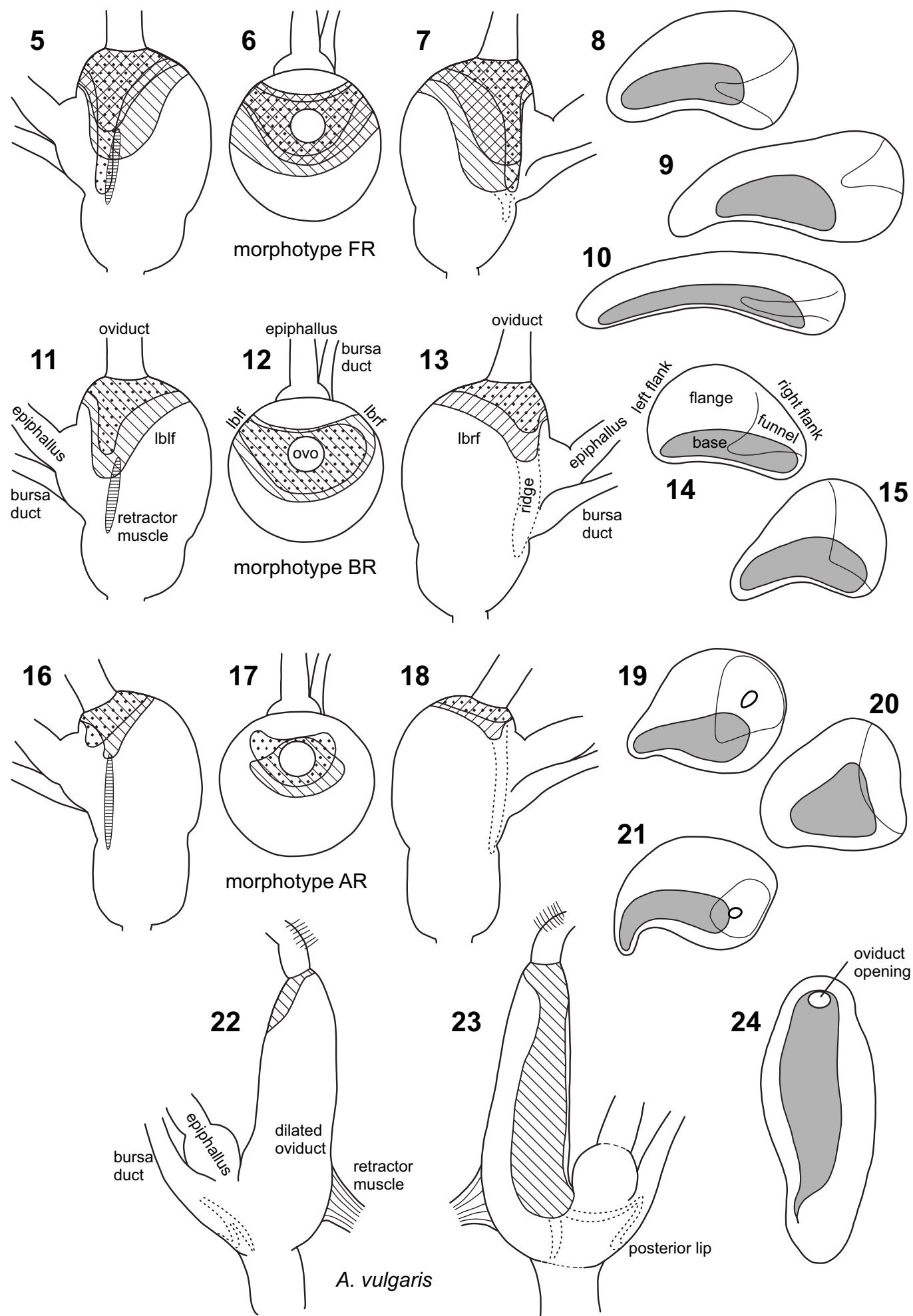

9

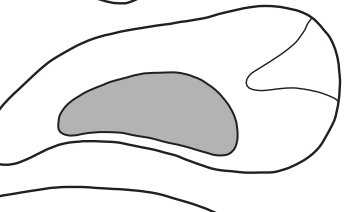

10

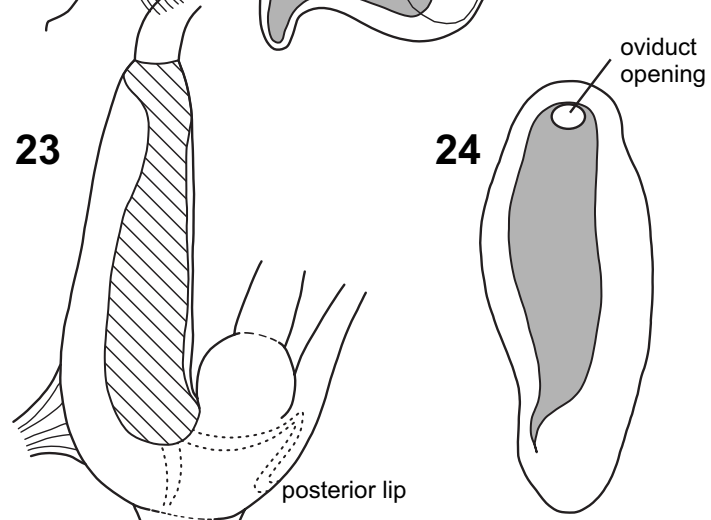

Figs 5-24. Variability of the ligula within and between morphotypes of A. ater s.1. (5-10 - FR; 11-15 BR; 16-21 - AR) and A. vulgaris (22-24). Figures on the left show schematic views of the atrium, indicating the intra-morphotype range of configurations of the ligula base on the inside of the atrium: each variant configuration is distinguished by a different pattern of hatching or spotting. The ridge on the inside of the atrium is indicated with a dashed line and the site of attachment of the retractor muscle with horizontal hatching. Figures on the right show the range of shapes of the flattened-out ligula (viewed from the inside), distinguishing the base (attached to the atrium or oviduct wall) from the surrounding free-hanging flange. In the FR and BR morphotypes of A. ater s.l. a spongy funnel-shaped area of the ligula is shown; at the tip of the funnel is the oviduct opening, but this is often difficult to discern. In the AR morphotype the opening of the oviduct is usually instead surrounded by a circular swelling, and the opening is more apparent (Figs 19-21). Abbreviations: ovo - oviduct opening, lbrf - ligula base, right flank, lblf - ligula base, left flank 
with intermediate characters between all forms, particularly often between forms AR and FR, suggesting common interbreeding. Despite this morphological variation, all these forms are clearly distinguishable from A. vulgaris, or were so until the latter arrived and started to hybridise.

(1) A trium and dilated

o vi d u c t

(Figs 5-7, 11-13, 16-18, 25, 26, 30, 33, 35, 37)

The upper (proximal) atrium is very large, muscular, and more or less spherical, thus making it the most prominent structure of the distal genital tract. It often displays a prominent lateral bulge beside the epiphallus insertion. A strong retractor muscle anchored on the body wall attaches along the distal half to two-thirds of the atrium, close to the epiphallus insertion. The free oviduct is narrow and thin walled and opens into the proximal end of the upper atrium, though usually not exactly apically.

(2) I n s e r t i o n of d u c t s

(Figs 1, 7, 13, 18, 25, 26, 30, 33, 35, 37)

With the slug opened as recommended, the common insertion of epiphallus and bursa-duct is on the back of the atrium (facing the right body wall) and thus, unlike in $A$. vulgaris, not visible. To reveal the insertions, the atrium and oviduct retractors must be detached, and the atrium turned over (as in Figs 25, $30,33,35,37)$. An exception is some young specimens, in which the insertions of epiphallus and bursa-duct may be partly visible on the posterior side of the atrium. In the natural position, the epiphallus insertion is anterior to that of the bursa-duct. An imaginary line connecting the insertions of bursa-duct, epiphallus, and oviduct forms a triangle with the side connecting bursa-duct and epiphallus very short. The length of the other two sides differs between morphotypes.

\section{(3) L i g u $1 \mathrm{a}$}

(Figs 5-21, 28, 32, 34, 36, 39)

The ligula of an adult specimen lies in the upper atrium and is very large, filling the entire interior and dominating the view when the atrium is opened (Figs 27, 31). The way the ligula folds up to fit into the limited space varies between and within morphotypes.

The central part of the ligula base lies at the proximal end of the upper atrium, around where the oviduct inserts onto the outside of the atrium. The base is extended into two lobes, each of which, together with the attached flange, we will call a "flank". The two flanks reach down along opposite sides of the atrium wall, like a saddle, flanking both sides of the common opening of epiphallus and bursa-duct (Figs 5-21). In the intact atrium, the bases of the two flanks thus roughly face each other, but in the atrium opened up from the side they may appear to follow a C-shape (Figs 3, 28, 34, 36), which is how some authors describe the ligula of A. rufus (e.g. NOBLE 1992, HATTELAND et al. 2015).

Imagine looking downwards at the closed atrium, with the oviduct pointing upwards (this would require detaching the oviduct retractor) and the insertions of epiphallus and bursa-duct pointing horizontally away from the viewer (Figs $6,12,17$ ). Then, if the atrium were transparent one could observe one flank extending to the right of the oviduct (subsequently called "right flank") and the other one to the left ("left flank"). The length and width of each flank of the ligula base vary considerably between the morphotypes of $A$. ater s.l. Also varying is the breadth of the ligula base on the side opposite to the insertions of epiphallus and bursa-duct (Figs 5-7, 11-13, 16-18).

In many specimens, the base of the tip of the left flank is considerably thickened, pedestal-like, and the atrium wall around this tip is often distorted, forming a prominent side bulge visible from outside the atrium. CHEVALLIER (1972) called slugs with such a bulge "form A of A. rufus rufus".

The width of the ligula flange (attached around the margin of the base and projecting into the inner atrium) varies considerably around its circumference. It is always very narrow, sometimes hardly visible, along the side towards the epiphallus/bursa-duct opening. The flange is always considerably wider on the opposite side and usually bigger on the right flank, gradually diminishing towards the left flank (Figs 8-10, 14, 15, 19-21). There is considerable variation between, and partly within, the morphotypes.

The position of the oviduct opening within the ligula varies. It is either more or less directly underneath the insertion of the oviduct onto the outside of the atrium or somewhere on the right flank and then connected through a tunnel of variable length running within the ligula base. In the latter case, the opening is most often at the margin of the base.

(4) Posterior lip and

a s s o c i a t e d ridge

(Figs 7, 13, 18, 34)

The posterior lip is a structure named by ALLGAIER (2014) that we find only in A. vulgaris and its hybrids. It occurs inside the proximal atrium, just short of the entrance of the bursa-duct, and continues as a ridge in both directions, towards the lower atrium and as far as the edge of the ligula base (Figs 22, 23, 41). Only the ridge is present in $A$. ater s.l. The width and prominence of the ridge vary between the morphotypes. It may pass the distal margin of the openings of epiphallus and bursa-duct and then enlarge somewhat to form a knob (Figs 3, 7), but it never forms 
a structure like the posterior lip of $A$. vulgaris (described below).

\section{(5) E p i p h a l l u s}

(Fig. 29)

The inner wall of the distal epiphallus is covered with many small tubercles. They are smaller than in A. vulgaris, most often pointed, and arranged in c. 6-12 (usually 9-11) longitudinal rows. However, the arrangement of the tubercles into rows is much less regular than in $A$. vulgaris. We found no difference between morphotypes within $A$. ater s.l.

\section{MORPHOTYPE FR}

(Figs 5-10, 25-32)

In the area of Görlitz, this morphotype was mainly and commonly found at synanthropic sites and could be orange, brown, or black. It disappeared from synanthropic sites after the invasion by A. vulgaris (REISE et al., unpublished observations). Our study material consists of slugs collected before the invasion and of slugs collected more recently from synanthropic sites in SW Poland. It was morphologically and genetically classified with individuals from Roussillon and Dijon, France, and genetically with Continental specimens called $A$. cf. empiricorum by RowsOn et al. (2014a).

(1) A t ri u m a d o viduct

The lower atrium is usually small but sometimes up to half the size of the upper atrium, rarely even the same size.

\section{(2) I n s e r t i o n of d u c t s}

Epiphallus and bursa-duct insert onto the distal part of the upper atrium, so usually rather far from the oviduct (e.g. Fig. 7), but there were rare exceptions in specimens from around Görlitz.

\section{(3) L i g u l a}

Both flanks of the ligula base are well developed (Figs 5-10). The base at least of the right flank almost always extends to the level of the bursa-duct opening (Fig. 7); the left flank is as long or a little shorter (Fig. 5). The width of the base varies considerably (Figs 5-10). The flange in most individuals is considerably wider on the right flank, forming a big flap, and the widest part extends from the tip of the right ligula base (Figs 9, 10), gradually diminishing from there towards the left flank. However, occasionally the flange is as wide on the left flank as on the right flank.

In one particularly prominent form found in two populations in and near Görlitz the ligula base is extremely narrow and long (Fig. 10), stretching from the distal end of the upper atrium, via the oviduct opening, to the distal end of the opposite atrium wall. The flange of such a ligula is almost evenly narrow along its full length. Compared to the usual big flap formed by the flange of the right flank, this ligula gives a much less bulky impression when the upper atrium is opened.

A canal-like groove flanked by a double fold leads from the oviduct opening towards the outer margin of the flange; usually the folds first run parallel close together and then diverge like a funnel (Figs 8-10). Within the funnel the flange often shows a spongy texture. The funnel can be wide or narrow, and sometimes hard to recognise. CASTILLEJO et al. (2019) illustrated the groove in both retracted and everted genitalia and highlighted it as a character distinguishing $A$. rufus from $A$. ater s.s.

(4) Posterior li p a n d

a s s o c i a t e d ri d ge

The ridge running from the base of the ligula's right flank is not prominent. It turns towards the distal margin of epiphallus and bursa-duct opening, where it may thicken to form a small knob. From there, the thin ridge continues distally (Fig. 7).

\section{MORPHOTYPE BR}

(Figs 11-15, 33-36)

In and near Görlitz, this morphotype was mainly found at synanthropic sites and could be brown or black. It disappeared after the arrival of $A$. vulgaris. Type BR groups morphologically and genetically with slugs commonly found in England (Table 1).

(1) A tri u m a nd dilated o v i d u c t

The upper atrium is externally as in FR. The lower atrium tends to be small but may be up to the size of the upper atrium (Fig. 35).

(2) In sertion of duct s

Epiphallus and bursa-duct insert most often distally, far from the oviduct insertion. But occasionally (also in reference populations) they may be shifted up to halfway towards the oviduct insertion.

\section{(3) L i g u 1 a}

The base of the right flank of the ligula is usually much shorter than in most specimens of morphotype FR, usually ending at a level close to the upper margin of the epiphallus opening (Fig. 13). The widest part of the flange is shifted from the end of the right flank towards the centre of the ligula (Figs 14, 15). This means that there is no big flap covering the ridge.

The funnel structure is similar to that in the FR morphotype but tends to open wider. The par- 
allel-sided groove leading from the oviduct towards the funnel is typically much shorter than in FR and may be absent. Hence CASTILLEJO et al.'s (2019) use of the groove to distinguish $A$. rufus from $A$. ater s.s. is not reliable with morphotype BR.

(4) P o s t e rior li p a d a s s o c i a t e d ri d g e

The ridge starting at the tip of the right base is much wider and more prominent than in morphotype FR. It runs straight towards the lower atrium, not getting particularly close to the epiphallus and bursa-duct openings (Figs 13, 34).

\section{MORPHOTYPE AR}

(Figs 16-21, 37-39)

This morphotype was found in and near the town of Görlitz and in hills further south along the northern Czech border. These individuals were black or dark brown. It was most common in natural woodland. As A. vulgaris has been slow to invade larger complexes of natural woodland in SE Saxony, form AR can still be found there. At synanthropic sites before the invasion of $A$. vulgaris, haplogroup ar occurred, with one exception, only in morphological intermediates between AR and FR or between AR and BR. Our morphotype AR genetically and morphologically largely matches $A$. ater s.s. from northern Europe, including material

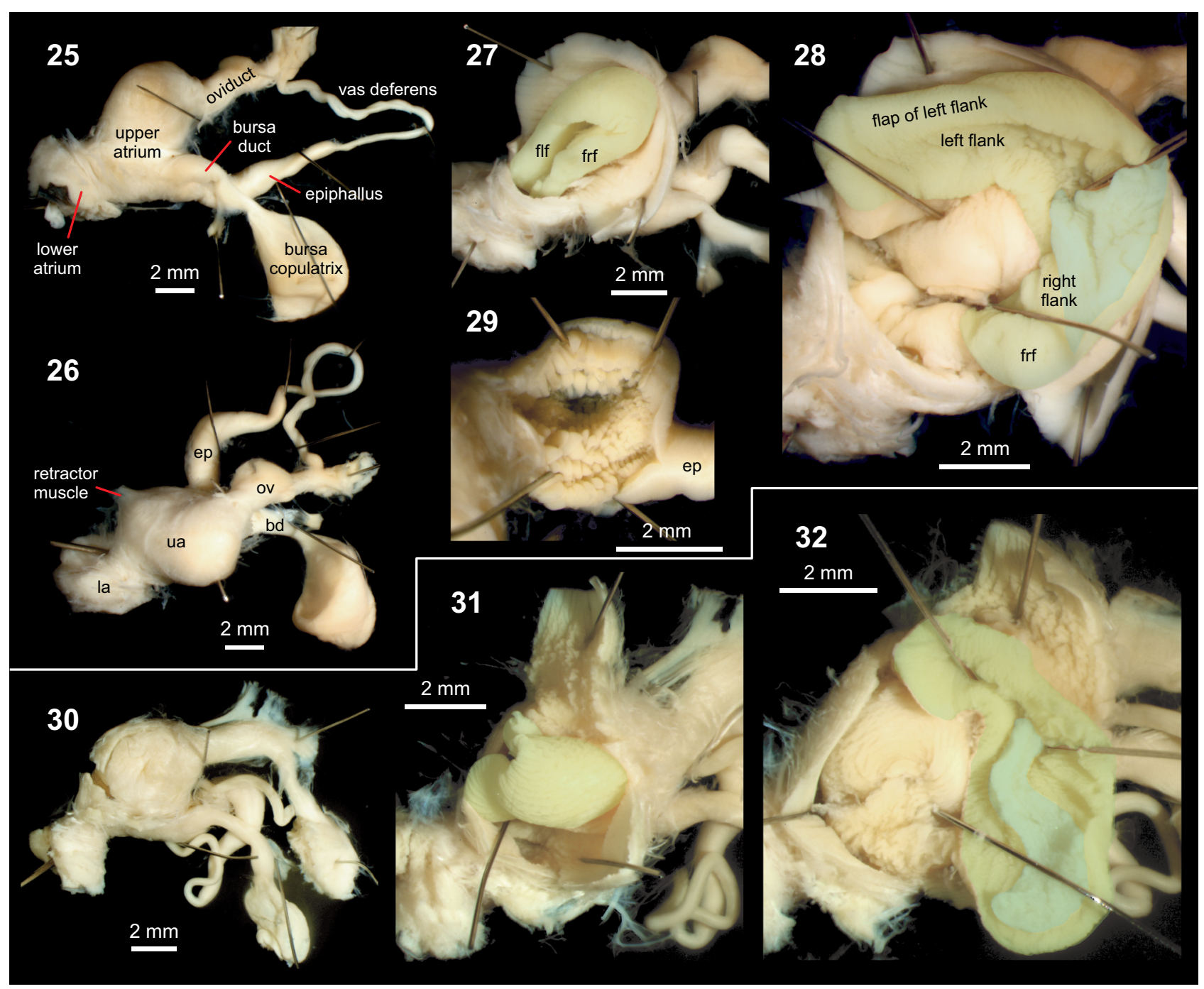

Figs 25-32. Genital anatomy of two individuals of A. ater s.1., morphotype FR: 25-29 - SMNG p20100, Pisarzowice, near Lubań, PL (leg. 2014); 30-32 - SMNG p17128T1, Zgorzelec, PL (leg. 2010). 25, 30 - genitalia oriented as when the slug is first opened (although in 30 the atrium had already been opened but then folded back); 26 - the back side of the same genitalia as in 25;27, 31 - the folded-up ligula on first opening the atrium; 28,32 - the atrium pinned out; 29 - tubercles inside distal part of epiphallus. Ligulas are shaded olive, and the funnel turquoise. Abbreviations: bd - bursa-duct, ep - epiphallus, la - lower atrium, ua - upper atrium, flf - flap of left flank, frf - flap of right flank, ov - oviduct 


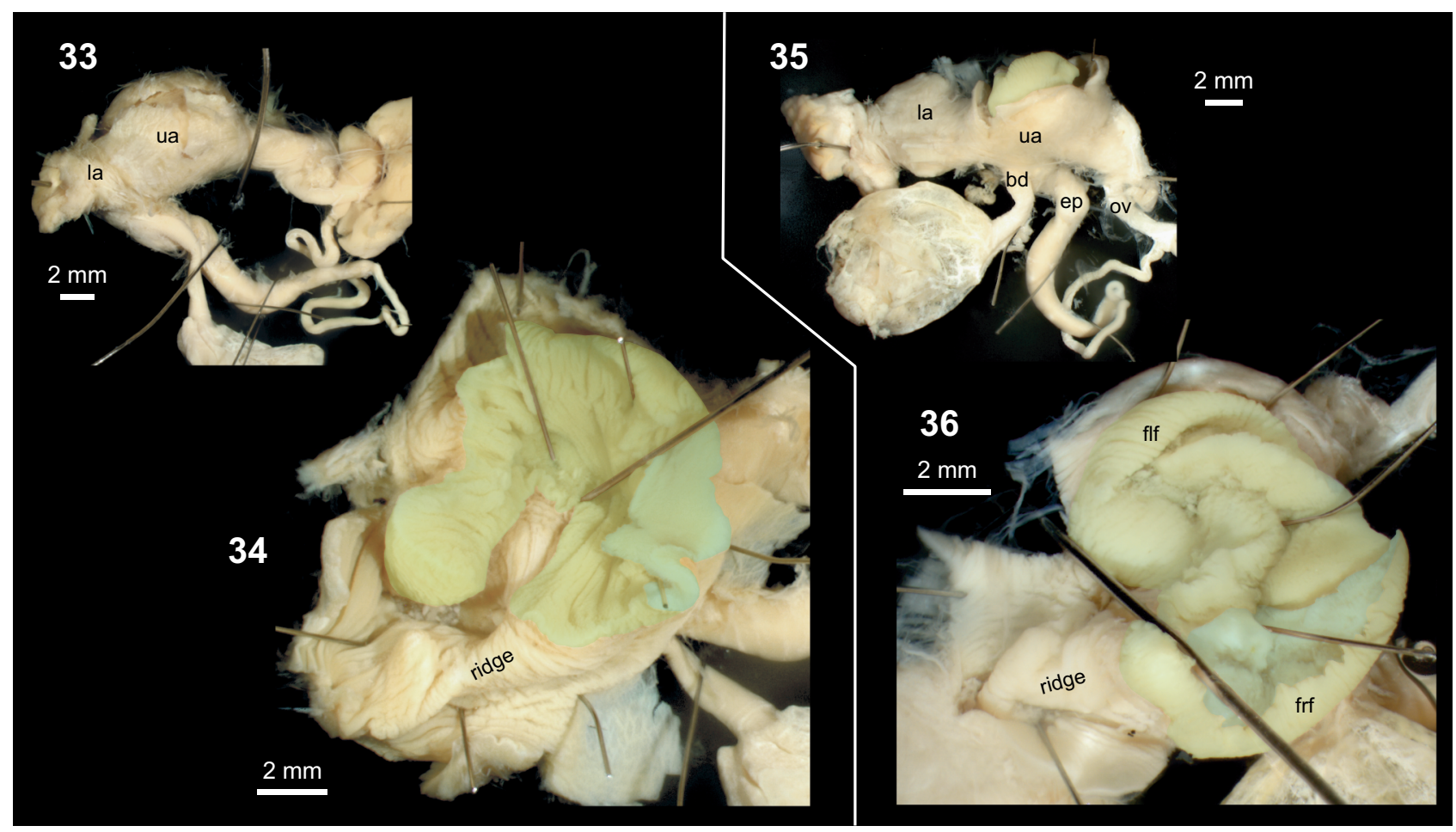

Figs 33-36. Genital anatomy of two individuals of A. ater s.l., morphotype BR: 33, 34 - SMNG p9431T2, Bogstrasse, Görlitz, DE (leg. 2001); 35, 36 - SMNG p23305, New Alresford, Hampshire, UK (leg. 2015). 33, 35 - genitalia oriented as when the slug is first opened, although these atria had already been opened but then folded back. Ligulas are shaded olive, and the funnel turquoise. Abbreviations: bd - bursa-duct, ep - epiphallus, la - lower atrium, ua - upper atrium, flf - flap of left flank, frf - flap of right flank, ov - oviduct

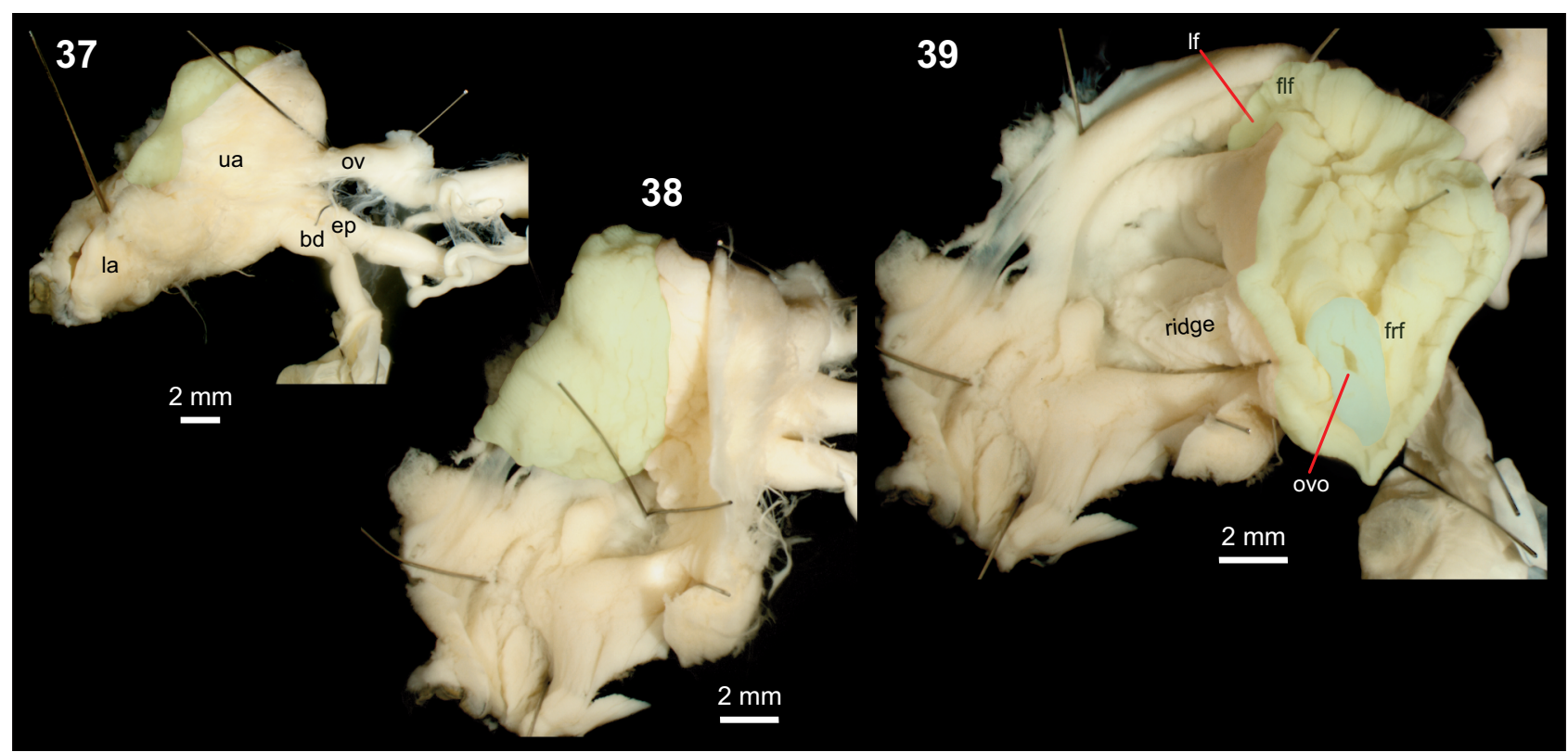

Figs 37-39. Genital anatomy of A. ater s.1. morphotype AR (SMNG p18714, Glashütte, Erzgebirge, DE, leg. 2014): 37-39 - progressive stages of opening the atrium to reveal the ligula (37 - the atrium has been folded back together to indicate the intact form). The ligula is shaded olive, and the ring around the opening to the oviduct is shaded turquoise. The base of the right flank of the ligula is virtually absent. Abbreviations: bd - bursa-duct, ep - epiphallus, la - lower atrium, ua - upper atrium, flf - flap of left flank, frf - flap of right flank, lf - left flank of ligula, ovo - opening of oviduct, ov - oviduct 
from localities in Scotland, Lithuania, Sweden, and the Faroe Islands.

The characters distinguishing form AR from forms FR and BR are mainly in the shape of the ligula but also in the relative size of upper and lower atrium and in the insertion of epiphallus and bursa-duct.

(1) A tri u m a d oviduct

The lower atrium tends to be larger than in morphotypes FR and BR (Figs 18, 37), and the upper atrium to be somewhat smaller. However, most slugs from our local German populations, and also our reference specimens from Scotland, had a big, muscular upper atrium comparable to morphotypes FR and BR. The lower atrium was never small in our Scandinavian, British, and Faroe Island reference specimens, but in specimens from Lithuania it was as small as in the other morphotypes. In the German populations the lower atrium was considerably more variable, spanning the full range of these reference populations.

\section{(2) I n s e r t i o n of d u c t s}

The insertions of epiphallus and bursa-duct on the upper atrium are usually considerably more proximal, closer to the oviduct insertion (Figs 16, 18, 37). However, we also found individuals with these two insertions as in morphotypes FR and BR.

\section{(3) L i g u 1 a}

The ligula base is smaller than in the other morphs, extending considerably less far distally, so that the whole ligula appears as a more compact structure fixed only on the apical atrium wall (the area where the oviduct inserts) (Figs 16-21). The base of the right flank is short or even virtually absent. If present, it may run as far as the epiphallus opening, but only if this lies particularly close to the oviduct. The base of the left flank is always present, but rather short; this is presumably the basis for NOBLE's (1992) description of the ligula as "pointed at the distal end". The flange is always considerably wider on the right flank and middle part than on the left flank. As the ligula base is so short, the flange is accordingly smaller, thus forming the bowl-shaped (rather than C-shaped) ligula described as typical of A. a. ater by NOBLE (1992); but it may also be much thicker and then be not as convoluted as otherwise or as in the other morphotypes (also in specimens from reference populations).

The opening of the oviduct is typically surrounded by a thickened ring structure, rather than the funnel structure of the FR and BR morphotypes (Figs 19, 21, 39). However, this seems not always to be the case in Central European populations of morphotype $\mathrm{AR}$, possibly reflecting a history of introgression with morphotype FR or BR. In some reference populations the ring structure lies within a wide funnel reminiscent of morphotype BR. But we have not observed the parallel-sided groove leading from the oviduct opening; CASTILlEJO et al. (2019) used its absence as a character distinguishing A. ater s.s. from A. rufus.

(4) Posterior lip a n d a s s o c i a t e d ri d ge

The ridge is similar to that of morphotype BR but less prominent (Figs 18, 39).

\section{ARION VULGARIS}

(Figs 2, 22-24, 40-42)

(1) A trium and dilated o v i d u c t

(Figs 2, 40)

The upper, muscular atrium is smaller and not nearly as swollen and muscular as in A. ater s.l. Instead, the distal genitalia are dominated by a strong dilated oviduct. The thin oviduct connecting proximally to this muscular part is similar to that in $A$. ater s.l. (though usually shorter). Instead of the strong atrium retractor of $A$. rufus, a strong retractor inserts onto the distal part of the dilated oviduct.

\section{(2) In sertion of d u c t s \\ (Figs 23, 40)}

Epiphallus and bursa-duct enter the upper atrium proximally, inserting onto a lateral bulge of the atrium just beside the insertion of the dilated oviduct. In a specimen opened as described above, these insertions are thus visible, posterior to the oviduct insertion, without having to detach any genital retractor muscle (although in mature specimens, the bursa and/or the spermoviduct may have to be pushed aside). In contrast to the triangular arrangement in A. rufus, the insertions of oviduct, epiphallus, and bursa-duct lie roughly along a straight line (in that order).

\section{(3) L i g u 1 a}

(Figs 2, 22-24, 41)

The ligula is in the dilated oviduct. If the slug has been opened as described above, and no genital retractor cut, before we open the oviduct the ligula base is on the wall of the oviduct lying upwards, away from the body wall. A cut along the oviduct in line with the retractor muscle allows one to turn over the ligula (Figs 2, 41), which should then be fully visible and undamaged.

The ligula is not bent and folded up as in A. ater s.l. but extended along the length of one side of the dilated oviduct; in comparison with $A$. ater s.l., one flank of the base is missing. The insertion of the thin oviduct is at the proximal end of the ligula base. The ligula takes the shape of a long boat with the ligula 
base corresponding to the bottom of the boat, the flange its sides. and the bow pointing towards the atrium (DAVIES 1987). Our illustrations (Figs 24, 41) show the distal end of the oviduct orientated downwards (Figs 24, 41), so we will refer to the flange on the left side of the boat as the right flange (we imply no homology with the left and right flank in $A$. ater s.l.). The width of the flange is asymmetric, though much less so than in A. ater s.l., and it is also generally narrower and varies less between specimens. The right flange is thicker and stronger than the left but forms only a bulge rather than the prominent flap in A. ater s.l. At the proximal end (the stern of the boat), the flange running closely around the opening of the thin oviduct is very narrow. The opening of the thin oviduct is directly underneath its insertion: there is no tunnel running through the ligula base. The most prominent ligula structure is the bow of the boat, where both longitudinal folds meet distally and project as a thick tongue into the atrium (Fig. 41); this tongue is attached only within the dilated oviduct. In a few individuals, a small single or double fold extends along the base, reminiscent of the two folds flanking the funnel-like structure on the right flank of the ligula in typical FR and BR.
(4) Posterior lip and a s s o c i a t e d ridge

(Figs 22, 23, 41)

A ridge, generally less prominent in A. vulgaris than in A. ater s.l., leads to the opening of the bursa-duct, where it expands and forms a loop. This creates the spoon-shaped structure that ALLGAIER (2014) referred to as the posterior lip. The other end of the spoon continues as a small longitudinal fold towards the lower atrium.

(5) E p i p h a l l u s

(Fig. 42)

The inner wall of the distal epiphallus contains longitudinal rows of big tubercles which are usually arranged in 5-6 well-ordered rows. Sometimes there are only 2 or 3 rows of big tubercles, and in this case there may be a few additional rows of smaller tubercles.

\section{MORPHOLOGICAL INTERMEDIATES BETWEEN A. VULGARIS AND A. ATER S.L.}

The genital morphology of intermediates varied extremely much, with a continuum of characters be-

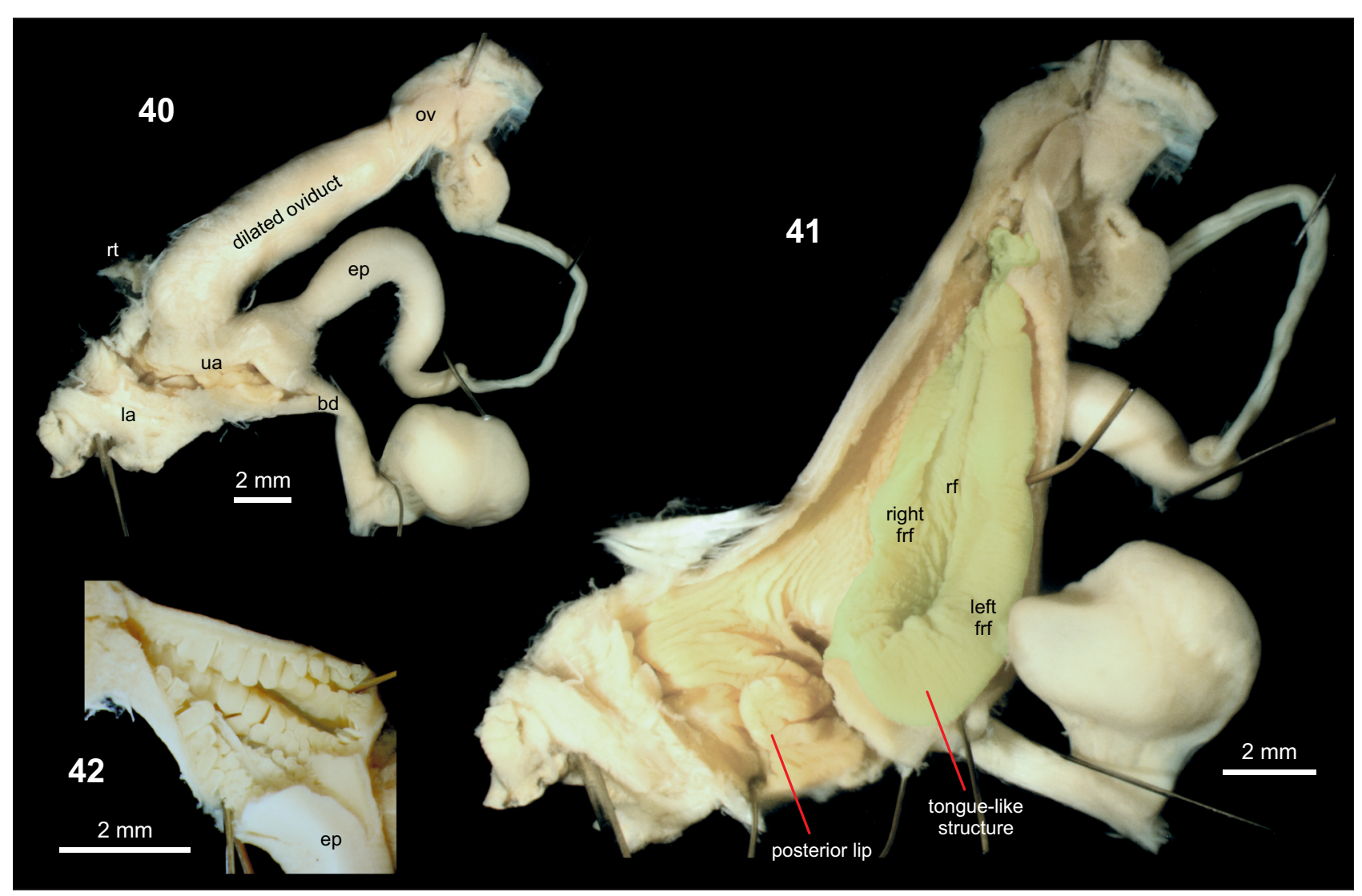

Figs 40-42. Genital anatomy of A. vulgaris (SMNG p17650, Rutschung P, Görlitz, DE, leg. 2005): 40 - the dissected genitalia closed back together to indicate the intact form; 41 - the atrium and distal oviduct opened to reveal the ligula (shaded olive: the left flank of the ligula is absent, and its flap is too small to show here); 42 - tubercles inside distal part of epiphallus. Abbreviations: bd - bursa-duct, ep - epiphallus, la - lower atrium, ua - upper atrium, frf - flap of right flank, rf - right flank of ligula, ov - oviduct, rt - retractor muscle 


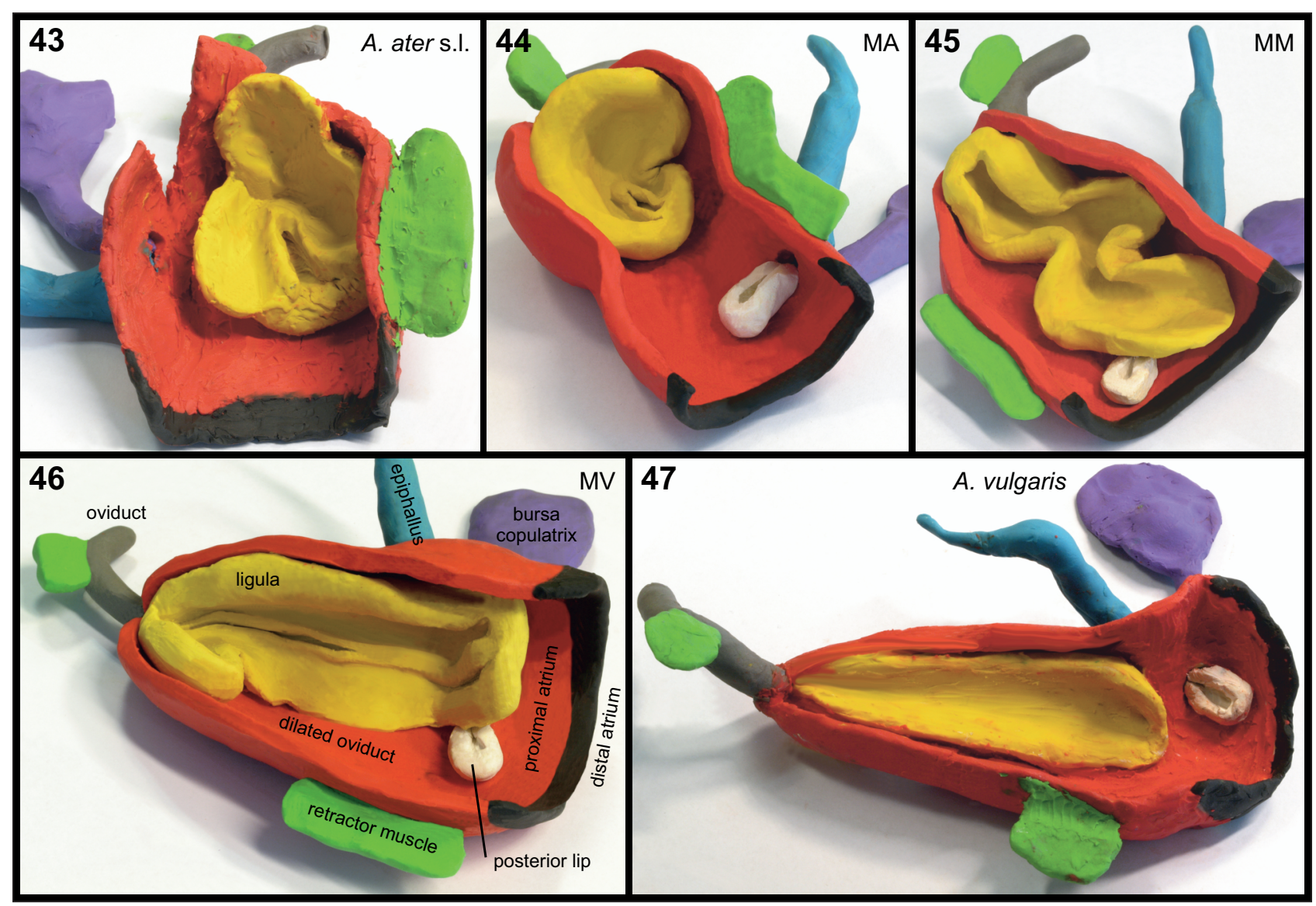

Figs 43-47. Plasticine models of the distal genitals of A. ater s.l. (43), A. vulgaris (47) and morphological intermediates MA (44), MM (45), and MV (46)

tween $A$. ater s.l. and A. vulgaris (Figs 48-58). We divided the intermediates into three categories: those with genitalia recognisably closer to either A. ater s.l. (MA: Figs 48-50) or A. vulgaris (MV: Figs 57, 58) and those intermediates in which we could not decide which parent species was closer (MM: Figs 51-56). However, the classification is partly subjective because of the continuity of the variation, especially with atrium/oviduct and ligula shape. It was particularly difficult to draw a line between MV intermediates and $A$. vulgaris because the latter is quite variable with respect to width and length of the dilated oviduct. For this reason, we took a conservative approach and classified doubtful specimens as A. vulgaris. Slugs classified as MV had to show characters never seen in our pure $A$. vulgaris reference population.

For the intermediate forms, it was difficult to decide whether the ligula-bearing part should be called atrium or oviduct. In MA- and MM-intermediates we will term it "upper atrium", reflecting the morphological similarity with the configuration of $A$. ater s.l. We term it "dilated oviduct" in MV-intermediates, as in A. vulgaris.
MA - A. ATER S.L.-LIKE INTERMEDIATES

(Figs 48-50)

MA-intermediates look like $A$. ater s.l. at first glance, particularly regarding the size and the shape of atrium and oviduct, but at least one of the other characters (usually posterior lip and/or epiphallus tubercles) are indicative of $A$. vulgaris.

(1), (2) A t r i u m a n d dilat e d

oviduct, insertion of d uct s

In an anatomical investigation considering only external features of the distal genital organs, MA forms would usually have been assigned to $A$. ater s.l. They share the spherical shape of the upper atrium, the retractor inserting on its side, the thin oviduct inserting at its proximal end, and the common insertion of epiphallus and bursa-duct on the distal part of the upper atrium on the side facing the body wall (Fig. 48). The only external indication, not present in most individuals, is a shift of the insertions of epiphallus and bursa-duct towards the A. vulgaris-typical configuration; that is the epiphallus inserts proximal to, rather than beside, the bursa-duct and thus roughly on a straight line between bursa-duct and oviduct. 


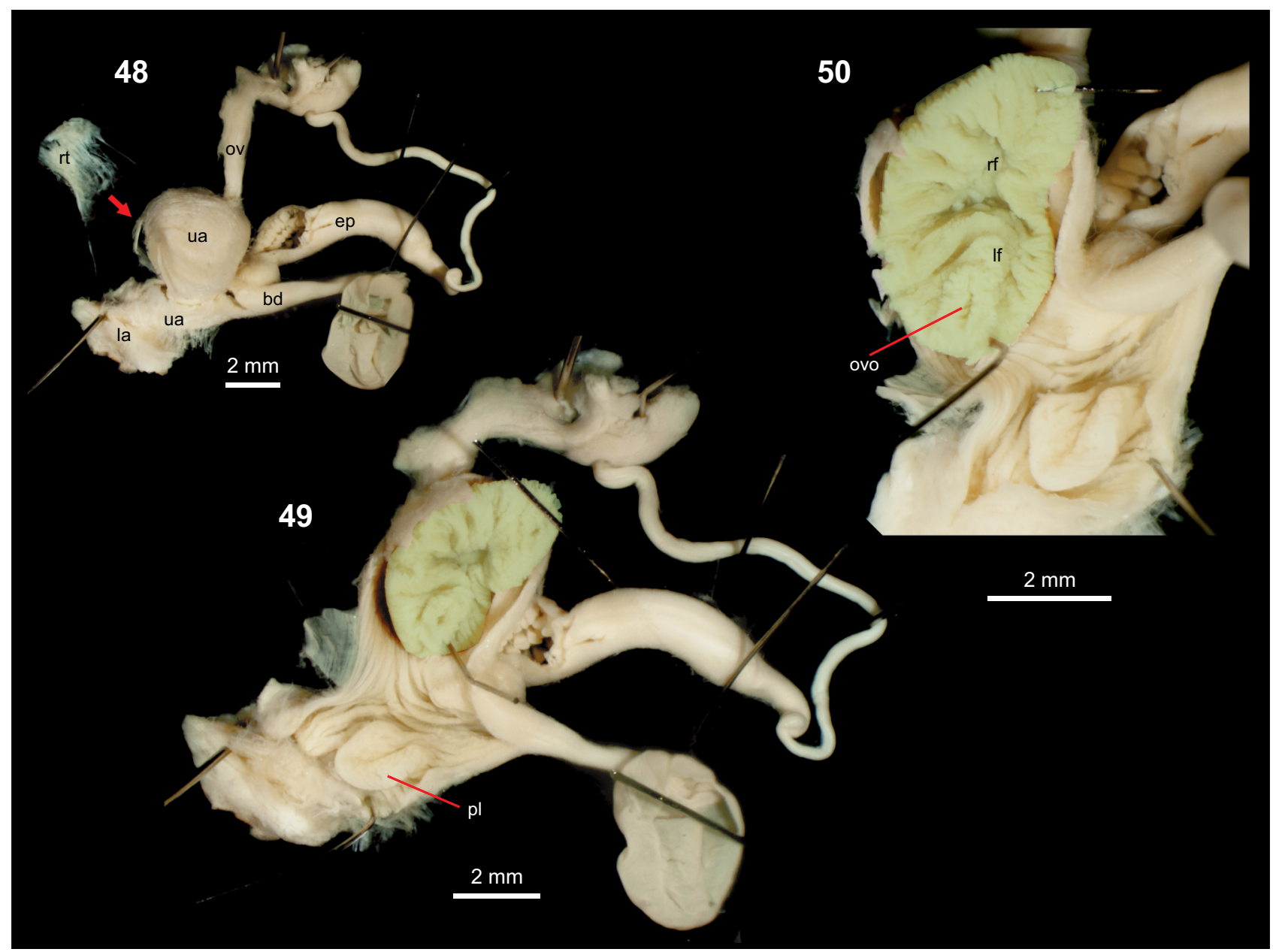

Figs 48-50. Genital anatomy of a morphological intermediate between A. ater s.l. and A. vulgaris but closer to A. ater s.l. (classified as MA; SMNG p18901, Rutschung P, Görlitz, DE, leg. 2013): 49, 50 - the atrium is shown opened to reveal the ligula (shaded olive). The distal part of the epiphallus has been opened to reveal the tubercles. This is one of the less typical specimens with the oviduct opening on the left flank of the ligula. Abbreviations: bd - bursa-duct, ep - epiphallus, la - lower atrium, ua - upper atrium, lf - left flank of ligula, rf - right flank of ligula, ovo - opening of oviduct, ov - oviduct, $\mathrm{pl}$ - posterior lip, rt - retractor muscle

\section{(3) L i g u l a}

In most MA-intermediates, the general appearance of the ligula is like that of $A$. ater s.l., a big rightflank base with a large flange and a big or small to very small left-flank base with a big or small flange. In such $A$. ater s.l.-like ligulas, the opening of the oviduct is usually just under the insertion of the oviduct. Often, but not always, there is the double fold on the ligula base typical of morphotypes FR and BR.

However, a few MA-intermediates (found only in the Rutschung P area) differ in the shape of the ligula: the flange is generally shorter and stronger than in A. ater s.l. so that it is not folded up within the atrium. This gives the ligula an appearance of an oval plate (Fig. 50). The base of its left flank is extremely short, but the appended flange is thick and long. Most distinctive is a shift of the entrance of the oviduct towards this left flank: the opening is at the margin of the base or even close to the tip of the flange and with a tunnel running from there to the oviduct. This configuration of the oviduct entrance is different from $A$. vulgaris, in which the oviduct opens underneath the oviduct insertion onto the atrium, and different from A. ater s.l., in which it either is like in A. vulgaris or runs through a tunnel into the right flank; but it may also be found in some MMintermediates. Also distinctive in these individuals is that the ligula base of the right flank does not run closely alongside the opening of epiphallus and bursa but lies some distance away. The oviduct opening is surrounded by a thickened ring structure reminiscent of AR, which might indicate that in these cases the parental A. ater s.l. is form AR.

(4) Posterior 1 i p a n d

a s s o c i a t e d ridge

Some slugs have a posterior lip like A. vulgaris (Figs $49,50)$, but it may be somewhat untypical. Many others have a simple ridge like in $A$. ater s.l. or a knob-like thickening, and a few have something intermediate. 


\section{(5) E p i p a $11 \mathrm{us}$}

Most MA-intermediates have an epiphallus with only big tubercles, typical of $A$. vulgaris, or they have big tubercles with a patch of small tubercles. Only rarely is the configuration like in A. ater s.l.

\section{MM-INTERMEDIATES}

(Figs 51-56)

(1), (2) A t ri u m a n d d il a t e d oviduct, insertion of ducts (Figs 51, 54)

The general external appearance of the distal genitalia is something between $A$. ater s.l. and A. vulgaris. The upper atrium may be just prolonged; then it looks like an unusually stretched atrium of $A$. ater s.l. or an unusually compressed, short, and very wide oviduct of A. vulgaris (Fig. 54). Alternatively, a spherical upper atrium is proximally prolonged with a similarly muscular but slightly narrower part (Fig. 51).

The insertions of epiphallus and bursa-duct are displaced from the back side of the atrium (typical of $A$. ater s.l.) towards the right side (as in $A$. vulgaris, though they may still be slightly hidden). Furthermore, there may be a slight bulging of the distal right side of the atrium causing the insertions of the epiphallus and bursa-duct to twist more parallel to the oviduct (i.e. more like in A. vulgaris). The retractor inserts, as in $A$. ater s.l., onto roughly the distal half of the atrium (although, if the atrium would be considered as a compressed dilated oviduct, the insertion would be at the position typical of $A$. vulgaris). Sometimes, there are many muscle fibres stretching over the full length of the atrium, as in some $A$. ater s.l. but never in A. vulgaris.

\section{(3) $\mathrm{L} \mathrm{i} \mathrm{g} \mathrm{u} 1 \mathrm{a}$}

(Figs 52, 53, 55, 56)

The ligula stretches the entire length of the prolonged atrium. Since the base of the right flank reaches distally as far down as the openings of epiphallus and bursa-duct (as in some forms of $A$. ater s.1.), this flank is similarly prolonged as the atrium. It is wider than in A. vulgaris. The base of the left flank is almost fully reduced, as in A. vulgaris, but a curtain-like flange hangs into the atrium. The opening of the oviduct may be on the tip of this flange or in the base, close to the oviduct insertion on the outside of the atrium. The flange of the right flank may be narrow and stout, as in A. vulgaris, or quite broad and strongly folded. Some individuals have a small single or double fold stretching along the base of the ligula, reminiscent of the folds flanking the funnel-like structure on the right flank of the ligula in FR and BR.
(4) P o s t e r i o r 1 i p

(Figs 52, 55)

Most often there is a posterior lip as in A. vulgaris, but it is sometimes absent or of untypical shape. A few have something intermediate between a posterior lip and the knob present in some A. ater s.l.

\section{(5) E p i p h ll u s}

The inner structure of the epiphallus is most often a mix of rows of small tubercles and rows of big ones, but sometimes there are only big tubercles and rarely only small tubercles.

\section{MV - VULGARIS-LIKE INTERMEDIATES}

(Figs 57, 58)

\section{(1), (2) A tri u m a n d dilated}

oviduct, insertion of ducts

(Fig. 57)

The dilated oviduct of MV intermediates looks like a particularly stout (short and wide) A. vulgaris oviduct. A strong retractor inserts on the distal half of the dilated oviduct. Epiphallus and bursa-duct insert on the proximal end of the lateral bulge of the atrium (as in A. vulgaris).

\section{(3) L i g u 1 a}

\section{(Fig. 58)}

The ligula has the general boat-like appearance of $A$. vulgaris, but it is wider, and the flange on the right side may be more flap-like (i.e. broader in extent and thinner in thickness) and is then slightly folded, roughly halfway along its length. Its distal end reaching into the atrium has the typical tonguelike appearance of $A$. vulgaris. At the proximal end, the ligula often does not end by just curving around the oviduct opening (as in A. vulgaris) but extends a little way further distally (Fig. 58); that is, the left flank of the ligula is not completely reduced as in $A$. vulgaris. The flange on this left flank is enlarged, to a varying extent, giving the impression of a small curtain covering the opening of the thin oviduct. This opening may be directly under the insertion (as in A. vulgaris) or run through a short tunnel into the big (right) flank of the ligula (as is common in $A$. ater s.l.). In some individuals, a small single or double (rarely triple) fold stretches along the base of the ligula (Fig. 58), reminiscent of the folds flanking the funnel-like structure on the right flank of the ligula in FR and BR.

\section{(4) P o s t e r i o r 1 i p}

The posterior lip is almost always present (Fig. 58) and only rarely of a shape intermediate between a posterior lip and knob or otherwise untypical. 


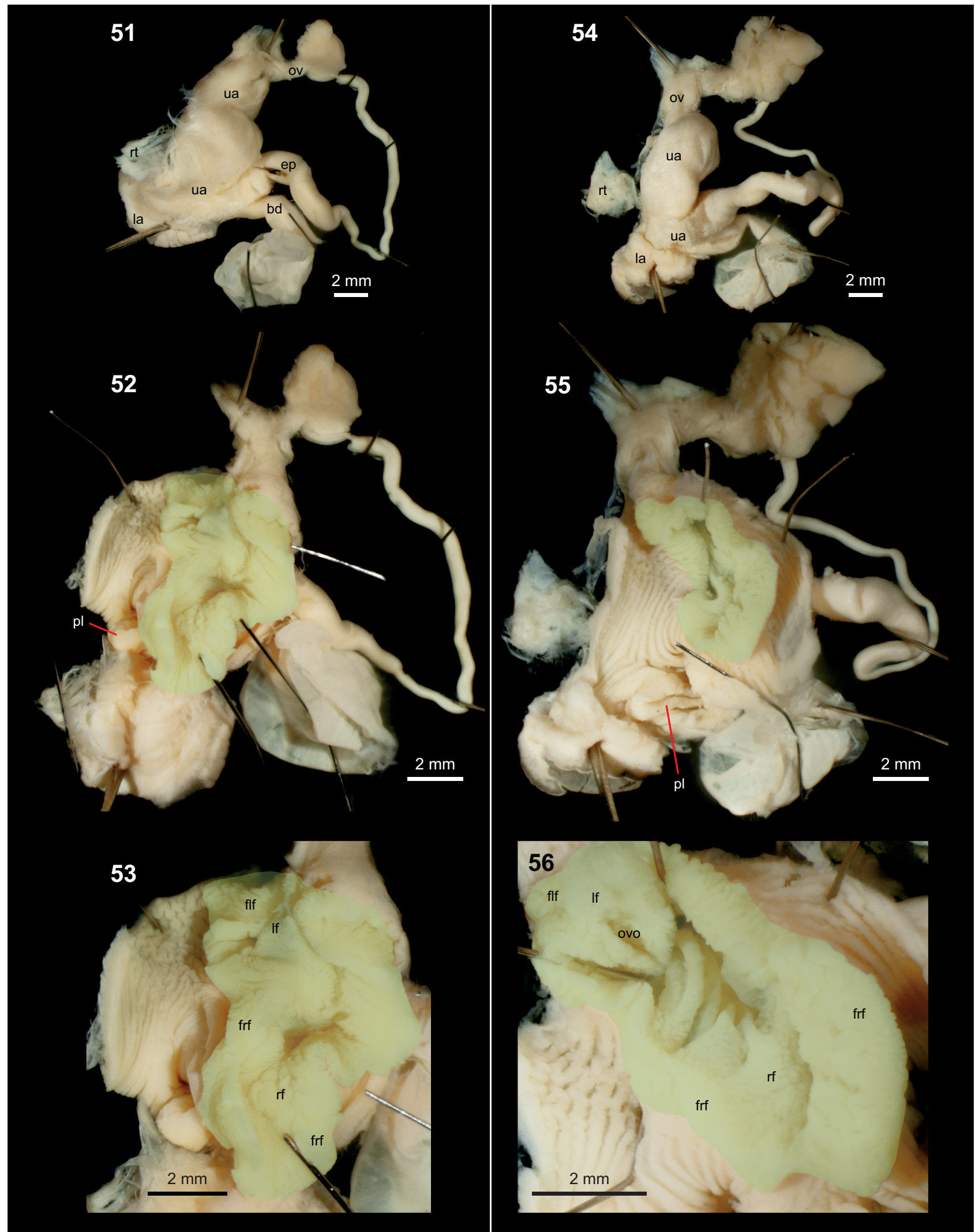

Figs 51-56. Genital anatomy of two morphological intermediates between A. ater s.l. and A. vulgaris, classified as MM: 51-53 - SMNG p17855, Rutschung P, Görlitz, DE (leg. 2008), 54-56 - SMNG p18912, Rutschung P (leg. 2013). The lower four photographs show the atrium opened to expose the ligula (shaded olive). Abbreviations: bd - bursa-duct, ep - epiphallus, la - lower atrium, ua - upper atrium, flf - flap of left flank, frf - flap of right flank, lf - left flank of ligula, rf - right flank of ligula, ovo - opening of oviduct, ov - oviduct, $\mathrm{pl}$ - posterior lip, $\mathrm{rt}$ - retractor muscle 


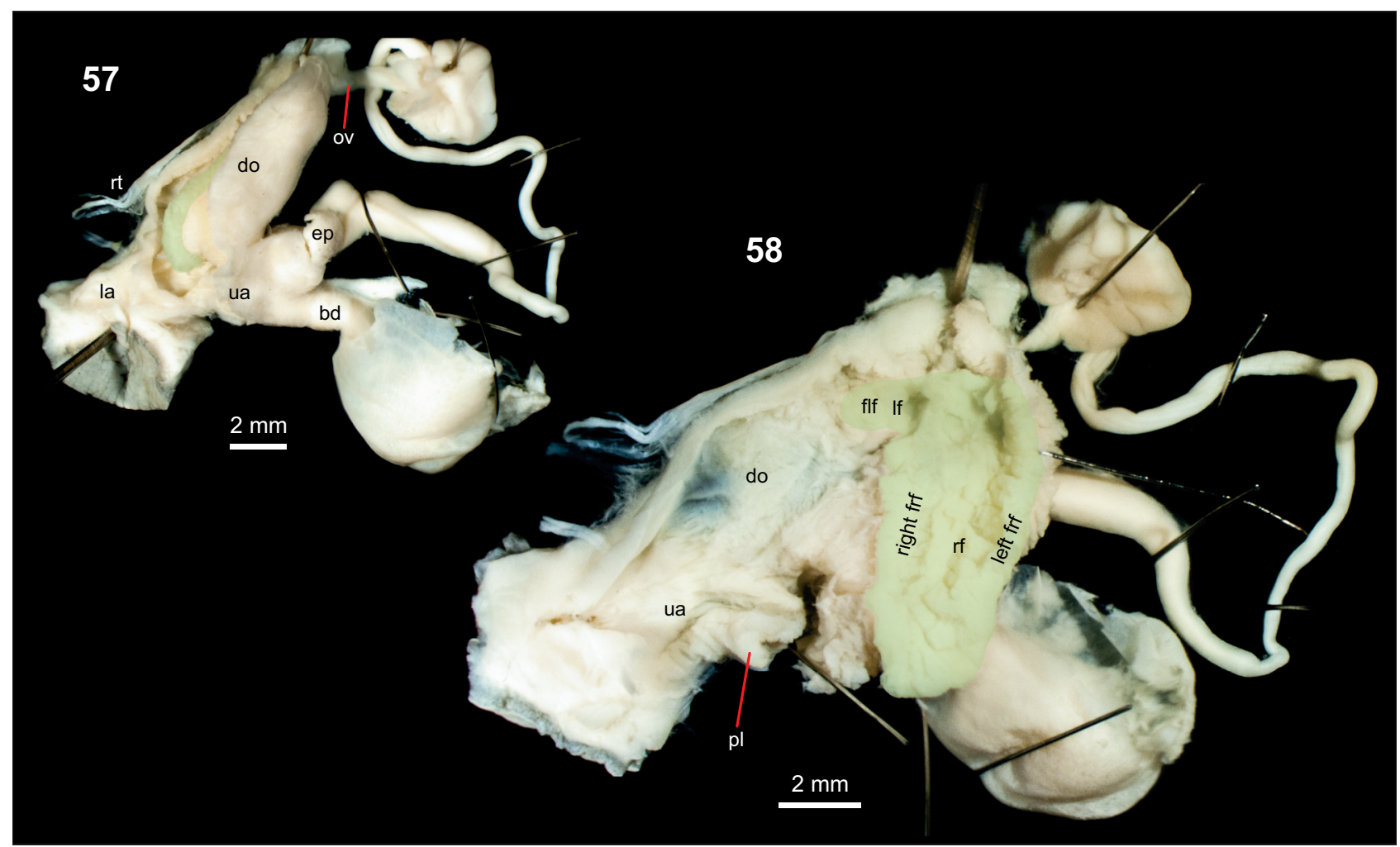

Figs 57-58. Genital anatomy of a morphological intermediate between A. ater s.1. and A. vulgaris but closer to the latter (classified as MV; SMNG p18873, Rutschung P, Görlitz, DE, leg. 2014): 57 - the dissected genitalia closed back together to indicate the intact form; 58 - the atrium and distal oviduct opened to expose the ligula (shaded olive). Abbreviations: bd - bursa-duct, do - distal oviduct, ep - epiphallus, la - lower atrium, ua - upper atrium, rf - right flank of ligula, flf - flap of the left flank, frf - flap of right flank, lf - left flank of ligula, rf - right flank of ligula, ov oviduct, $\mathrm{rt}$ - retractor muscle

\section{(5) E p i p h a $11 \mathrm{us}$}

The internal structure of the epiphallus always contains the large tubercles typical of A. vulgaris, sometimes in combination with a field of small tubercles.

\section{RESULTS: PERCENTAGES OF INTERMEDIATE MORPHOTYPES IN THE POPULATIONS AND AGREEMENT WITH GENETICS}

Amongst the 2,055 specimens from the monitoring sites, we found $77(3.7 \%)$ individuals that were morphologically intermediate between $A$. ater s.l. and A. vulgaris. If we also include the other material from the neighbourhood of Görlitz (another 1,915 specimens), the percentage remains $3.7 \%$. However, these values must slightly misrepresent the percentage of intermediates, as it also includes years before A. vulgaris arrived and after $A$. ater s.l. disappeared. If including only those years when $A$. vulgaris was found to co-occur with $A$. ater s.l. or with morphological intermediates, the percentage rises slightly to $4.3 \%$. The 77 intermediates from the monitoring sites were classified as $27 \%$ MA morphotype, $18 \%$ MM morphotype, and 55\% MV morphotype, so a majority were morphologically closer to A. vulgaris.
Table 3 shows that morphological intermediates included all three $A$. ater s.l.-haplogroups, but a majority $(67 \%)$ had a $v u$ haplotype, including $67 \%$ of the MA-intermediates, which were morphologically close to A. ater s.l. Seven of the eight morphologi-

Table 3. Agreement between morphology and partial-COI haplogroups in putative hybrids (MA, MM, MV) and parental forms

\begin{tabular}{|c|c|c|c|c|c|}
\hline \multirow{2}{*}{ Morphotype } & \multicolumn{4}{|c|}{ Haplogroup } & \multirow{2}{*}{ Total } \\
\hline & $f r$ & $b r$ & ar & $v u$ & \\
\hline A. ater s.l. & 19 & 10 & 22 & $2(4 \%)$ & 53 \\
\hline MA & 1 & 2 & 1 & $8(67 \%)$ & 12 \\
\hline MM & 1 & 1 & 1 & $3(50 \%)$ & 6 \\
\hline MV & 0 & 0 & 1 & $5(83 \%)$ & 6 \\
\hline A. vulgaris & 0 & 0 & 0 & $7(100 \%)$ & 7 \\
\hline
\end{tabular}


Table 4. Agreement between morphology of A. ater s.l. and partial-COI haplogroups in specimens from the study area and, below, from reference populations

\begin{tabular}{|c|c|c|c|c|c|}
\hline \multirow{2}{*}{ Morphotype } & \multicolumn{4}{|c|}{ Haplogroup } & \multirow{2}{*}{ Total } \\
\hline & $f r$ & $b r$ & $a r$ & $v u$ & \\
\hline FR & $12(67 \%)$ & 0 & $4(22 \%)$ & $2(11 \%)$ & 18 \\
\hline BR & $2(15 \%)$ & $9(69 \%)$ & $2(15 \%)$ & 0 & 13 \\
\hline AR & 0 & 0 & $9(100 \%)$ & 0 & 9 \\
\hline Uncertain & $5(38 \%)$ & $1(8 \%)$ & $7(54 \%)$ & 0 & 13 \\
\hline Reference FR & $9(100 \%)$ & 0 & 0 & 0 & 9 \\
\hline Reference BR & 0 & $7(100 \%)$ & 0 & 0 & 7 \\
\hline Reference AR & 0 & 0 & $8(100 \%)$ & 0 & 8 \\
\hline
\end{tabular}

cal intermediates that were found to have A. ater s.l. haplotypes had been classified either as MM or MA, and only one as MV. Amongst those slugs morphologically classified as pure A. ater s.1., two (4\%) had a $v u$ haplotype; these exceptions were from urban sites where $A$. vulgaris co-occurred with $A$. ater s.l. No slugs classified morphologically as $A$. vulgaris had haplotypes associated with $A$. ater s.l., but only seven had been sequenced.

By design, the $A$. ater s.l. individuals from the reference populations were of the expected haplogroups.
Arion ater s.1. from Görlitz that we identified morphologically as one of the three morphotypes also usually were of the expected haplogroup, but there were a reasonable number of exceptions (10, i.e. 25\%) for the FR and BR morphotypes (Table 4). Note that this disappointing error rate is liable to have been inflated by our tendency to select the difficult cases (morphologically) for sequencing. Thirteen $(25 \%)$ out of 53 genotyped $A$. ater s.l. from the neighbourhood of Görlitz had characters intermediate between the morphotypes, so we scored them as possible hybrids.

\section{DISCUSSION}

In a large proportion of the animal and plant kingdoms taxonomy relies on morphological differences in reproductive organs. Potential reasons include the morphological complexity of genitalia, their fast rate of evolution, stabilising selection against genitalia too aberrant to allow copulation, and possibly a selective advantage to being unable to mate with related species. The distal genitalia in Arion are indeed quite complex, but experiments demonstrate that even morphotypes as different as $A$. ater s.l. and $A$. vulgaris can exchange sperm (DREIJERS et al. 2013). This tolerance might be associated with the high intraspecific morphological variation, because tolerance both weakens the stabilising selection and may have allowed introgression events. Nevertheless, our expanded character set was sufficient to identify morphological differences between three races of A. ater s.l., which tend to differ also in genetics and geographical distribution. Furthermore it was possible to quantify the morphological intergradation between $A$. ater s.l. and $A$. vulgaris as a result of recent hybridisation.

A particularly informative character was the ligula. We initially found it difficult to work out its three-dimensional structure in $A$. ater s.l. as the general impression when opening the atrium is influenced by the way the ligula flange is folded up inside (which may be partly a matter of chance), by the side from

which the atrium has been opened, and by whether the ligula has been damaged in this process. It is also difficult to depict and describe such complex three-dimensional structures (see e.g. QUICK 1947, Chevallier 1974, Noble 1992, HATTELAND et al. 2015). One key conceptual advance was distinguishing ligula base and flange, which helped to isolate the more fundamental and consistent morphological differences.

\section{MORPHOLOGICAL INTERMEDIATES AS HYBRIDS OF A. VULGARIS WITH A. ATER S.L.}

Our morphological data provide strong evidence that the invasive $A$. vulgaris hybridised with $A$. ater s.l. The latter had already been collected in natural and synanthropic habitats in Görlitz and surroundings decades before $A$. vulgaris appeared, and the invader's arrival and spread in the area were closely monitored (REISE et al. unpublished data). Nowhere did we find morphological intermediates before the arrival of $A$. vulgaris.

Our results are in line with observations that $A$. ater s.l. and $A$. vulgaris try to mate with each other and sometimes transfer spermatophores reciprocally, both in the laboratory (ROTH et al. 2012, DREIJERS et al. 2013) and in the field (ALLGAIER 2014, REISE \& DREIJERS unpublished observations). Genetic 
analyses of three Swiss populations also proved that hybridisation occurs frequently (ZEMANOVA et al. 2017).

Morphological intermediates between A. vulgaris and $A$. ater s.l. have been reported before (FALKNER 1981, ENGELKE et al. 2011, HATTELAND et al. 2015, ZEMANOVA et al. 2017), but our study provides the first thorough description of their diversity, placing them along a continuum between the parental species. One use of our enriched character set is to recognise potential hybrids that would previously have passed as one of the parental species. Secondly, our classification of intermediate forms allows us to distinguish hybrids from the other sorts of untypical specimens (maybe other species or accidents of development). As an example, CHEVAlLIER (1972: figs 6, 7) depicted two "untypical" specimens of $A$. vulgaris and $A$. rufus from a site in the Hautes-Alps (SW France) of which at least one now looks to us like a hybrid between $A$. vulgaris and $A$. ater s.l. Indeed CHEVALLIER considered this option (1972: 12). Thirdly, our full set of characters allows a finer classification of morphological intermediates. One may question the particular delineation into named morphs, but it is clear that MA morphs share more characters with A. ater s.l. and MV morphs more with $A$. vulgaris. It would be desirable to calibrate our morphological classification against a fine-scale measure of genetic admixture, for instance using the microsatellites developed by ZEMANOVA et al. (2015, 2017). In the meantime we treat their rough correspondence as a useful working hypothesis.

We feel quite confident about distinguishing intermediates from $A$. ater s.l. but less so about distinguishing them from $A$. vulgaris. This might reflect the lack of a true standard $A$. vulgaris, as its area of origin is still unresolved. The standard we used was also an invader population. Considering that $A$. vulgaris seems to have mated with native $A$. ater s.l. reasonably often in our study area (and in the Swiss Alps: ZEMANOVA et al. 2017), one may presume that it has done so repeatedly along its invasion route. If such crosses lead to fertile hybrids, models predict that an invading species will have undergone considerable introgression by genes of the native species (CURRAT et al. 2008). A long history of hybridisations with a succession of local populations of $A$. ater s.l. might also explain the occasional appearance in $A$. vulgaris of characters reminiscent of $A$. ater s.l., in particular a small single or double fold on the ligula base and, in the epiphallus, small tubercles sometimes co-occurring with the typical large tubercles.

The continuum of characters between $A$. ater s.l. and $A$. vulgaris suggests backcrossing in both directions. In the hybrids most like $A$. ater s.l., the two $A$. vulgaris characters that persist (epiphallus tubercles and posterior lip) are often not both present, sug- gesting that both might be absent in other hybrid individuals. Since hybrids similar to one parental species can be recognised morphologically only if they have at least one character of the other species, morphological evidence is liable to underestimate the degree of introgression in natural populations. Thus it was no surprise to find two individuals with the morphotype of pure A. ater s.l. but a partial-COI sequence of A. vulgaris (Table 3). Similarly, ZEMANOVA et al. (2017) reported occasional discordance in both directions between mitochondrial and multiple autosomal markers, also implying backcrosses over multiple generations.

The posterior lip, which around Görlitz is diagnostic of $A$. vulgaris, occurs in a population of $A$. ater s.l. near Tübingen, $500 \mathrm{~km}$ to the west of Görlitz (Allgaier 2014). Allgaier (2014) reports that in Tübingen the habitats of $A$. ater s.l. and $A$. vulgaris are distinct, and intermediates have not been found, but we wonder whether the posterior lip in A. ater s.l. is an indication of former introgression events. Arion vulgaris had turned up in that area in 1971 (SCHMID 1972), 22-41 years before the studies by Allgaier (2014). However, it remains to be investigated whether our set of five characters successfully classifies A. ater s.l., A. vulgaris, and intermediates in other populations.

\section{HOMOLOGY OF UPPER ATRIUM AND DILATED OVIDUCT}

Our study shows a continuum of the distal genital characters from A. ater s.l. to A. vulgaris via their morphological intermediates. This suggests that the ligula-bearing, proximal part of the upper atrium of A. ater s.l. is homologous to the muscular, dilated oviduct of $A$. vulgaris. Consequently, the upper atrium of $A$. vulgaris would be homologous with only the more distally positioned part of the upper atrium of $A$. ater s.l., that which includes the insertions of epiphallus and bursa-duct. Most species of Arion that have a ligula have it in the oviduct (e.g. A. hortensis, A. subfuscus, A. flagellus, A. franciscoloi: WIKTOR 1973, DAVIES 1987, BOATO et al. 1983), and this is also true of the closely related Ariunculus (HUTCHINSON \& REISE 2015), so we presume that the arrangement in A. ater s.l. is the derived state.

A smooth transition is also apparent in the ligula. The left flank of the ligula in A. ater s.l. is missing in A. vulgaris, but the intermediates exhibit a continuum. The right flank of the ligula of $A$. ater s.l. (in $A$. ater s.s. largely absent) forms almost the entire ligula of A. vulgaris: its terminal flange, particularly prominent in FR, corresponds to the tongue-like projection of $A$. vulgaris, which reaches with its tip into the atrium. The oviduct tunnel running through the base and sometimes even the flange of the ligula in 
A. ater s.l. is reduced in the intermediates and completely missing in A. vulgaris, in which the opening lies directly beneath the external insertion of the thin oviduct.

Less clear is how to interpret the small single or double fold sometimes to be observed on the base of the ligula of $A$. vulgaris. It is very reminiscent of the folds usually flanking the funnel-like surface of the ligula flange in FR and BR from the oviduct opening to the outer margin and may thus reflect introgression from $A$. ater s.l. However, we decided not to consider it as a character indicative of $A$. ater s.l. because too many otherwise typical $A$. vulgaris, including some in our reference population, had this character.

The homology is also indicated functionally: both ligula-bearing parts (the atrium in A. ater s.l. and the dilated oviduct in $A$. vulgaris) are everted at copulation, once the mating partners have coupled via the epiphallus-pedunculus complex, which is everted first (DrEIJERs et al. 2013, Allgaier 2014). The details of their positioning and use differ between the species (DREIJERS et al. 2013) but also within A. rufus (CHEVAlLIER 1974).

Traditionally, the ligula-bearing duct of $A$. vulgaris has been considered as part of the free oviduct (e.g. COLLINGE 1897a, CHEVALLIER 1974, LIKHAREV \& WiKTOR 1980, NOBlE 1992, CASTILlEJO 1998, RowsON et al. 2014a, b). However, QUICK (1952, 1960) recognised the homology with the atrium and pointed out that the situation was comparable in some other slug species: "It is shown that the dilated part of the lower part of the 'oviduct' in lusitanicus, subfuscus and hortensis contain a structure homologous with the ligula of ater and rufus, and which functions similarly in coitus, and it is suggested that this duct is really an extension of the atrium and is not the oviduct." (QUICK 1952: 99). Also DAVIES (pers. comm. 2002) wrote in notes from 1998 that, "In $A$. vulgaris etc. it [the ligula] is more or less contained in an extension of the atrium which should not be regarded as a widening of the oviduct proper." Arion distinctus exhibits a dimorphism in which one morph has an eversible distal part of the oviduct containing a ligula whereas in the other morph this part is missing, and a considerably reduced ligula lies in the atrium. The retractor muscle inserts onto the eversible part of the oviduct in the morph where this is present, but onto the atrium in the other morph, leading DE WINTER (1984) to propose that the eversible part is an extension of the upper atrium.

These authors seem to be proposing that the homology between the ligula-bearing structures in $A$. ater s.l. and $A$. vulgaris argues for naming this part of the oviduct in A. vulgaris as atrium. We disagree because, if we consider other groups of Arion and the related Ariunculus, the ancestral condition is most likely that the ligula lies in the oviduct. So, if anything, the homology is a reason to rename the ligula-bearing part of the atrium of $A$. ater s.l. We do not think this worthwhile. Nevertheless the ligula-bearing part of the oviduct in A. vulgaris and certain other Arion species deserves a special term such as "dilated oviduct" because it serves different functions to the rest of the free oviduct: (1) it everts during mating whereas the more proximal part does not; (2) after mating, the received spermatophore reaches the dilated oviduct (besides the atrium and bursa-duct) but never the more proximal part (DREIJERS at al. 2013). In A. ater s.l. the spermatophore remains in the atrium and bursa-duct (DREIJERS at al. 2013).

\section{MORPHOTYPES OF ARION ATER S.L.}

In our study area around Görlitz, we found three haplogroups of $A$. ater s.l. with subtly distinct genital morphologies, Their genetics and morphologies agree very well with populations elsewhere: form FR from Central and SE France (we deliberately avoided material from SW France), form BR from numerous populations in Britain, and form AR from northern Europe. We considered also separating the FR morph with the narrow ligula (Fig. 10) but refrained from doing so, because: (1) the basic morphological characters as well as the COI sequences group it with the typical form FR, and (2) we have not come across this morph beyond the surroundings of Görlitz.

For the morphological distinction of these three haplotypes, the ligula is the most important character. During our morphological study, it became apparent that three aspects strongly determined the general impression an investigator gets when looking at the ligula: (1) the way the atrium is opened and thus the direction of view, (2) length and width of the ligula base, and (3) the shape and strength of the ligula flange. The base in morphotype AR is small, and, if the flange is relatively thin (often but not always the case), this results in a bowl-like appearance. The "pointed distal end" of the ligula mentioned by NOBLE (1992) is the left flank, which is present in all three morphotypes but may sometimes appear more prominent in AR because the rest of the base is small. If the ligula is more glandular and thus thicker, the general appearance is more similar to FR and BR. The base in morphotypes FR and BR extends also on the right flank (usually less in BR), so that the general impression when opening the atrium from the side, roughly opposite to the insertions of epiphallus and bursa-duct, is a C-like bent structure. However, the extension of the flanks and the shape and size of the flange vary considerably and influence the way it folds up in the atrium. The clearest characters differentiating FR from BR are the shape of the ligula and the size of the ridge running on the inner atrium wall from the ligula base distally: The flange of the ligula 
in FR is largest at the tip of its right flank, and the ridge is small, while in BR the flange is largest more towards the middle, and the ridge is much bigger.

\section{F o r m A R}

We named the AR form according to its morphological and genetic agreement with the northern $A$. ater s.s., but the distal genitalia do not always agree with previous descriptions based on sizes of upper and lower atrium (e.g. QUICK 1960, KERNEY et al. 1983). The upper atrium may be as big as in the other morphotypes, and the lower atrium was often not as large as is typical. However, the latter was mainly the case with some slugs from our study area, and one may wonder whether this is due to introgression with other morphotypes. EVANS (1986) had also noticed that the distal genitalia of $A$. ater s.s. were more variable than had been recognised; he proposed that some of this morphological variability may be caused by gene flow from diverse local populations of $A$. rufus. In the British Isles and Scandinavia, hybridisation between $A$. rufus and $A$. ater s.s. has been inferred (CAIN \& WilliamSON 1958, EVANS 1986, Noble 1992, HATTELAND et al. 2015), and our results imply that this might have occurred also in Germany. Based on all characters, including ligula and mtDNA, we think that our morphotype AR corresponds with what is called $A$. ater s.s. by most Continental malacologists, ANDERSON (2005) and ROWSON et al. (2014a, b) or A. ater ater by many other British malacologists (e.g. QUICK 1960).

There is confusion in the literature about how far the distribution of $A$. ater s.s. extends beyond Britain and Scandinavia. Haplotypes with the ar group extend to northern Spain (QUINTEIRO et al. 2005, PfEnNinger et al. 2014, ZEMANOVA et al. 2016, CASTILlEjo et al. 2019), but we have found that at least some such Spanish slugs have a dramatically different mating behaviour to $A$. ater s.s. from the north and so may not be conspecific. CASTILLEJO \& RODRíGUEZ $(1991,1993)$ reported A. ater s.s. from northern Iberia, but their genital illustrations do not suggest this identification to us. JAECKEL (1962) reports $A$. ater s.s. from the Pyrenees and western Alps, but it is unclear on what evidence. Clearer evidence is the work of BOETTGER (1949a, b), who explicitly checked the genital anatomy of German A. ater s.l. (particularly black specimens) from Holstein, Berlin, Sachsen-Anhalt, Baden-Württemberg, Niedersachsen, Bremen, and Hessen. On the basis of the appearance of the atrium, he identified $A$. ater s.s. only from Holstein (bordering Denmark) and considered the rest black A. rufus. ZETTLER et al. (2006) confirmed it also from Mecklenburg-Vorpommern (NE Germany), and we have specimens from Lithuania (see also ADOMAITIS \& SKUJIENE 2016). In the Czech Republic and Slovakia no distinction has been made between
A. rufus and A. ater s.s. (HORSÁK et al. 2013). The same is mostly true of Poland (WIKTOR 2004), but CHEVALLIER's doctoral thesis (1974) identified some slugs from northwestern and southwestern Poland as A. ater s.s.; also ZEMANOVA et al. (2016) report an ar sequence from northern Poland. Thus our records from Görlitz, to which we can add Czech records from adjacent areas to the south, confirm a distribution range in Central Europe extending considerably further south than has been generally assumed.

\section{For m F R a n d B R}

Much less clear than with $A$. ater s.s. is the existence of two or more distinct forms of $A$. rufus. Although it was the COI sequences that first suggested to us the presence of these two different morphotypes in our region, there is a history of splitting A. rufus on morphological grounds. COLLINGE (1897a) distinguished two species based on where the epiphallus and bursa-duct inserted on the atrium: close to the free oviduct in A. rufus s.s. and much further distally in what he called A. empiricorum. Unfortunately, he did not mention on what material his study was based (although CHEVALLIER 1972 thought that his material was from Britain). However, in another paper COLLINGE (1897b) stated that $A$. rufus s.s. occurred on continental Europe only and $A$. empiricorum both on the British Isles and the Continent.

Based on extensive morphological comparisons of European (mainly French) big Arion, CHEVALLIER (1972, 1974) distinguished four subspecies of A. rufus, of which at least some seemed to interbreed. Two of his subspecies could be found in Central Europe and northern parts of Western Europe: (1) A. rufus rufus, mainly distributed through the NE of France, southern Britain, the Benelux countries, Germany, western Poland and south to Hungary and northern Italy and (2) A. rufus collingei found in France south of the area of A. r. rufus and at an isolated locality in SW Poland (only c. $100 \mathrm{~km}$ away from our study area). CHEVALLier (1972) equated Arion $r$. collingei with CollingE's (1897a) A. empiricorum but renamed it because he wanted to use the name $A$. empiricorum for the entire group, also including A. ater and A. vulgaris (i.e. in the sense of FÉRUSSAC 1819). CHEVALLIER distinguished his two subspecies of $A$. rufus by where the epiphallus and bursa-duct inserted onto the atrium (like COLLINGE 1897a) but also by the shape of the ligula: triangular in A. r. rufus and oval in A.r. collingei. Our morphotypes BR and FR do not show a consistent difference in the insertion of epiphallus and bursa-duct (this is variable in both forms), but BR morphotypes tended to have the insertion of epiphallus and bursa-duct nearer to the oviduct than in FR morphotypes. But more importantly, one could well consider the ligula of BR as triangular (as 
in A. rufus rufus, the form CHEVALLIER reported as in Britain) and that of FR as oval (as in A. rufus collingei).

Strangely, CHEVAllier $(1972,1974)$ did not comment on the conflicting statement by COLLINGE (1897b) that A. empiricorum (= CHEVALLIER's A. rufus collingei) rather than A. rufus (= CHEVALLIER's A. rufus rufus) was the form commonly occurring in Britain. We suspect that this discrepancy between studies is caused by COLLINGE mixing up names rather than by a real faunistic change over the intervening 75 years. In the same paper, Collinge (1897b) excluded $A$. ater s.s. from Britain, which also suggests carelessness or limited material. Our own observations of recently collected British material support CHEVALLIER (1972).

NOBLE (1992), in a study including morphological comparisons and allozyme electrophoresis, with a particular focus on Britain, searched for consistent, distinct differences within $A$. ater s.l. but could not find any. However, all his material of $A$. rufus (except samples from SW Europe) may have been from the area that CHEVALLIER (1974) considered as occupied by only one of his subspecies (A. r. rufus). Still, NOBLE (1992: 262) also reinvestigated specimens deposited by CHEVAlLIER at the Natural History Museum London (without specifying details) and could not detect differences between what CHEVALLIER had labelled as different subspecies.

Solely based on 16S DNA, RowsON et al. (2014a) distinguished two species of Arion rufus in Britain. They restricted the name $A$. rufus to the haplogroup commonly found in Britain (corresponding to our $b r$ COI haplogroup) and the name $A$. cf. empiricorum to the other species (corresponding to our fr COI haplogroup), of which they found only a single juvenile individual in Britain. All seven British A. rufus specimens with the $b r$ haplotype that we dissected were of morphotype BR, and we did not find FR morphotypes amongst the non-sequenced British $A$. rufus, so it is reasonable to equate ROWSON et al.'s $A$. rufus with our BR. The fr haplogroup seems to be the most widespread haplogroup in northwestern mainland Europe (see Results). Around Görlitz, it is associated with FR morphology, and this holds also with the limited material we have examined from elsewhere (three sites in France, also Sweden, Czech Republic, Poland, and further sites in Germany; also from Vancouver Island, Canada). So we equate the FR morphology with RowsON et al.'s A. cf. empiricorum.

ZEMANOVA et al. (2016) distinguished A. vulgaris, $A$. ater s.s., and $A$. rufus genetically and anatomically from a wide area of western and central Europe. However, none of the slugs considered by ZEMANOVA et al. (2016) belong to the $b r$ haplogroup, in part because they included few British samples. Nevertheless, the $b r$ haplogroup does occur sporadically in mainland Europe, although occurrences in Genbank data imply it is less common than fr. Around Görlitz the br haplogroup and BR morphotype are not rare, but less common than $\mathrm{fr}$ and FR.

\section{HABITAT SEGREGATION}

Our form AR differed from forms BR and FR in habitat preference. From synanthropic sites in Görlitz, we found only one morphologically pure AR, but numerous individuals appear to be a mixture of AR with FR and possibly with BR. Some such intermediate individuals had ar COI haplotypes. Otherwise, pure AR morphotypes were found in natural woodland only (though our number of collecting sites is very limited). Perhaps AR is the native form in our area, and BR and FR are later invaders, preceding $A$. vulgaris. FRÖMMING (1953), walking outside Berlin (250 km north of Görlitz) was struck by a population of orange A. ater s.l., commenting how untypical this coloration was in this region and that the typical colour was black. This and our genetic data suggest that synanthropic A. ater s.l. around Görlitz (and probably elsewhere in Central Europe) may be the outcome of historical introductions from different populations in Western Europe and the British Isles and their occasional interbreeding with each other and with the native form.

The invasion of $A$. vulgaris since about 1994 has changed the situation in the area of Görlitz considerably. Morphotypes BR and FR, and their intermediates, earlier common in synanthropic habitats, have largely disappeared from Görlitz (REISE et al. unpublished data), whereas AR is still rather common in natural woodland of eastern Saxony. This suggests that the reason for the resistance of AR and the disappearance of the others lies in their different habitat preferences: A. vulgaris in eastern Saxony is still largely restricted to synanthropic habitats.

A habitat analysis of slug assemblages in the German state of Nordrhein-Westfalen indicates that, similarly as in Görlitz, A. rufus had been widespread in open habitats before $A$. vulgaris turned up (KAPPES \& KOBIALKA 2009). But, in contrast to the situation in Görlitz, A. rufus is still living in woods in some areas of western Germany after A. vulgaris took over in synanthropic habitats (KAPPES \& KOBIALKA 2009, ALLGAIER 2014, own observations). Woodland populations in western Germany seem often to be orange or reddish-brown (SCHMID 1997, ALLGAIER 2014), whereas around Görlitz the woodland populations are usually black, the typical colour of $A$. ater s.s. The fr haplogroup of $A$. rufus is the native form in the Swiss Alps but is being displaced by A. vulgaris at lower altitudes (ZEMANOVA et al. 2017).

Habitat modification and fragmentation may lead to a breakdown of habitat-based isolation barriers (RHYMER \& SimBERLOFF 1996). The patchwork of 
small woods and open land around Görlitz seems prone to this. In this area, an analogous breakdown of reproductive barriers between ant species with different habitat preferences had been documented (SEIFERT et al. 2010). At one of our study sites (Rutschung P) in the countryside near Görlitz all three rufus-forms as well as their intermediates had been collected before or at the early stage of invasion by A. vulgaris. At this site two individuals showing morphologies intermediate between A. vulgaris and A. ater s.l. had ar COI haplotypes; this was also the case with one slug at another site near Görlitz. Thus, despite the general habitat segregation, A. vulgaris has introgressed with AR forms, as is known to

\section{TAXONOMY}

Between all our morphological forms of $A$. ater s.l., we found a more or less continuous range of intermediates in the study area, indicating common interbreeding. This makes it questionable whether it is appropriate to designate AR, BR, and FR forms as species. Similarly, morphological indications of interbreeding at the contact zones caused CHEVALLIER (1974) to consider his morphological forms of $A$. rufus as subspecies. There were also many samples elsewhere which he was not able to classify to one of his subspecies, which might indicate a much less clear distribution pattern than indicated on his maps.

The differences between the mitochondrial haplogroups are large: $f r$ and $b r$ are the most similar, differing by $5.0 \%$, whereas the most different are $f r$ and ar, differing by $6.9 \%$ (Table 2 ). In most animal groups such bar-coding differences would suggest a species difference, but pulmonate mitochondrial sequences can show unusually large intraspecific differences, in some species larger than our inter-haplogroup differences (PARMAKELIS et al. 2013). More fundamentally, if the putative taxa can hybridise, introgression may make mitochondria an unreliable guide to phylogeny. Amongst material collected in Spain, where Arion diversity is at its highest, we have found cases where some individuals in populations differing considerably in mating behaviour share a partial-COI sequence, and conversely where individuals in a population sharing the same mating behaviour have partial-COI sequences typical of different parts of the A. ater s.l. phylogenetic tree. Past introgression is a likely source of such disagreement. This is also a reason to distrust phylogenies of $A$. ater s.l. based on mtDNA sequences (cf. PELÁEZ et al. 2018).

Nevertheless we have shown here that there are fairly consistent morphological differences associated with these mitochondrial haplogroups. There occur in Scandinavia (VON PROsCHWITZ 1996, 1997, HAGNELL et al. 2004, RotH et al. 2012, HATTELAND et al. 2015).

Such genetic introgression might alter the strict habitat association of AR and/or A. vulgaris and consequently weaken their isolation. We have not noticed any indication for this in the case of AR, but there are indications that $A$. vulgaris is now invading woodland (SCHMID 1997, at various sites in BadenWürttemberg; VON PROSCHWITZ 1996, 1997, in deciduous woodland in Sweden; REISE unpublished observations in extensive pine forest near Königs Wusterhausen, Brandenburg; REISE et al. 2018a in deciduous woodland at the Rotstein, Saxony).

are also strong indications of a difference in the main ranges of these haplogroups, especially if we discount populations suspected to be recent introductions. Haplogroup $b r$ predominates in the British Isles, ar predominates in Scandinavia and neighbouring parts of north-western Europe, and fr predominates to the south of these regions. We therefore consider it reasonable to treat the morphotypes as subspecies. It would be desirable to have nuclear genetic data to support the morphological differences that we describe. Given the continuing hybridisation between these forms, genetic samples should ideally be selected from undisturbed habitat in the core of their distribution ranges. We have evidence that there are additional forms deserving similar taxonomic status from the southern part of the species' range in France and Spain (REISE et al. 2018b and further unpublished data).

One such form might be the parental population of $A$. vulgaris (ZEMANOVA et al. 2016). Might this also deserve only subspecific rank as a part of $A$. ater s.l.? Its partial-COI haplogroup is little more distant from the A. ater s.l. haplogroups than they are from each other (6.7-7.8\% vs $5.0-6.9 \%)$, and it also hybridises with $A$. ater s.l. On the other hand A. vulgaris is morphologically much more distinct, and morphological intermediates occur only during the invasion phase, then disappear. Judging from the shared derived character of the ligula in the atrium, our subspecies of $A$. ater s.l. are likely to form a monophyletic group; monophyly of $A$. ater s.l. is also not incompatible with the poorly resolved phylogenetic trees based on mitochondrial DNA (ROWSON et al. 2014a, PELÁEZ et al. 2018). Furthermore, we believe that it would be too disruptive to change the taxonomic status of A. vulgaris, so it should continue to be treated as a distinct species. 


\section{NOMENCLATURE}

LINNÆUS (1758: 652) described both A. ater and A. rufus. If we consider these taxa as conspecific, which name has priority depends on the first reviser. Already MÜLLER (1774: 2) treated ater as having priority, but he did not mention the name rufus (he used the earlier name subrufus for what LINNÆUS (1758) called rufus), so cannot count as a reviser. At latest, FLEMING (1822: 572) explicitly treated A. rufus as a variety of $A$. ater, and this is the priority consistently followed by others who consider the taxa conspecific.

The nominotypical $A$. ater ater (Linnæus, 1758) is our AR morphotype, but should $A$. ater rufus be applied to the BR or to the FR morphotype? As detailed by VAN REGTEREN ALTENA (1963), LINNAUS' (1758) description of rufus referred to his book on the Swedish fauna (LINNÆUS 1746; but the implied Swedish occurrence must almost certainly have been Arion fuscus: ODHNER 1951, vON PROSCHWITZ 1985), to German material described by ALDROVANDI (1644), and to the work of LISTER (1685), who described both British and French specimens. Because both BR and FR forms occur on the Continent, but FR or $f r$ are almost unknown in Britain (CHEVALLIER 1974, Rowson et al. 2014a), greater certainty is achieved by selecting a British specimen as the lectotype. Also this choice follows Recommendation 74A of the Code (ICZN 1999) in ensuring compatibility with the nomenclature of CHEVALLIER $(1972,1974)$ and Rowson et al. (2014a, b).

Hereby we designate as the lectotype of Limax rufus Linnæus, 1758 a now non-existing specimen amongst those described by LISTER (1685: 7) from "Amberry" in Yorkshire. Amberry is Almondbury, south of Huddersfield, which may still be pronounced as Lister wrote it and appears with spellings similar to Lister's in contemporary documents (SMITH 1961, TAYLOR 1975). The illustration of "Limax rufus" (LisTeR 1685: fig. 1 on tabula 2), to which LINNÆUS (1758) also refers (he originally indicated " p. 1" but in the 12th edition-LINNÉ 1767: 1081-corrected this to "t. 2. f. 1"), is plausibly of an individual from this population, since foreign localities, but not British ones, are consistently included in the captions to others of LISTER's (1685) figures, and Amberry is the single British locality for the species mentioned in the main text. In any case, since the illustration does not reveal anatomical characters, it is better to associate the lectotype with the named locality, from which fresh specimens can be collected, than to designate an illustrated specimen of uncertain origin. (Recommendation 74E of the Code (ICZN 1999) trumps Recommendation 74B, which applies only "other things being equal".) It is unlikely that any of LISTER's (1685) specimens of this species survive. In 1683 he deposited a col- lection of specimens illustrated in LISTER (1678) in the Ashmolean Museum, and an accompanying letter promised more; so perhaps the specimens described in LISTER (1685), the appendix to LISTER (1678), followed them. Nothing of this collection is known to have survived (MACGREGOR 2001).

We associate our BR morphotype with $A$. ater rufus because in Britain the $b r$ haplogroup is widespread (combining information from COI and $16 \mathrm{~S}$ sequences) whereas the fr haplogroup is known from only a single locality (RowsON et al. 2014a). Furthermore, all reddish specimens of $A$. ater s.l. from Britain that we have dissected are BR, which agrees with the results of CHEVALLIER (1974). Moreover, we have recently found the BR morphotype occurring commonly in Almondbury, now the type locality. In theory LISTER's (1685) red slugs might instead have been hybrids between $\mathrm{BR}$ and $A$. ater ater, or improbably early occurrences of presumably non-native species such as A. vulgaris or A. flagellus. These possibilities could be made irrelevant to the issue of taxonomy with the designation of an appropriate neotype, as is our future intention. Our Arion ater rufus (Linnæus, 1758) corresponds to RowSON et al.'s (2014a) Arion rufus and to CHEVALLIER's $(1972,1974)$ A. rufus rufus.

To find the appropriate name for the FR morphotype, we sought post-1758 descriptions of rufus-like slugs from continental Europe. We believe the name having priority is Limax ruber Garsault, 1764, which GARSAULT (1767: 376) described as a red brown slug, larger than Helix pomatia. His illustration (GARSAULT 1764: pl. 644; https://gdz.sub.uni-goettingen.de/id/ PPN496755056) is recognisably an Arion species on account of the position of the pneumostome. Judging from other illustrations, the pale lateral band in this illustration is merely the artist's device to indicate the round form. No locality was given, but the neighbourhood of Paris, where Garsault worked (WELTERSCHULTES et al. 2008) is the most reasonable assumption. This would be compatible with occurrences of $f r$ in that area (ZEMANOVA et al. 2016). However, it would be desirable to designate a neotype to remove all doubt about the correspondence of ruber with the FR morphotype, as is our future intention. The name of the FR morphotype becomes $A$. ater ruber (Garsault, 1764), corresponding to RowsON et al.'s (2014a) Arion cf. empiricorum and CHEVALLIER's (1972, 1974) A. rufus collingei.

\section{ACKNOWLEDGEMENTS}

Many volunteers working with us for a year or longer helped monitor the spread of $A$. vulgaris in and around Görlitz: VIVIEN BARTH, MANDY BENKE, EDGARS DREIJERS, ANDREAS FINKE, MiCHEL KRAHL, CHRISTIANE MATTHIEU, SABRINA MATTON, ClaUdia NATUSCH, Josefine SAUER, MARLEN Scheibe, EWA 
SCHENKMANN, KATRIN SCHÜTZE, ISABEL TAMGHARI, STEFANIE VISSER, FALK WAGENHAUSEN, and JULIANE WOJAN. For contributing further specimens, thanks also to KATRIN SCHNIEBS, TED VON PROSCHWITZ, GRITA SKUJIENĖ, LUTZ ZWIEBEL, KLAUS and EDITH REISE, and many colleagues from the SMNG. A few sequences were obtained by BS working in the laboratory of THIERRY BACKELJAU, funded under Synthesys grant BE-TAF-224; Thierry also stimulated the initial sampling of $A$. vulgaris in Görlitz. MARGRIT and GERHARD FALKNER helped us to access an old publication. FranCISCO WELTER-SCHULTES, DIETRICH
KADOLSKY, and RUUD BANK generously provided invaluable advice on the nomenclatural issues: it was Francisco who alerted us to GARSAULT (1764) and Dietrich to FLEMING (1822). We thank ELAINE BATES (Huddersfield Local Studies Library) for her assistance in confirming that Amberry was Almondbury and DUNJA SHARIF (Bodleian Library) and ANNA MARIE ROOS (University of Lincoln) for their help in our unsuccessful search for the original of LISTER's (1678) illustration. Thanks also to BEN ROWSON and TED VON PROSCHWITZ for their pertinent comments as referees.

\section{REFERENCES}

Adomaitis M., SKUJIENĖ G. 2016. Comparative analysis of ligulas of slugs Arion lusitanicus from Lithuania and Denmark. Scientific Bulletin of the Uzhgorod University (Series Biology) 40: 5-10.

AgUiar R., WinK M. 2005. How do slugs cope with toxic alkaloids? Chemoecology 15: 167-177. https://doi. org/10.1007/s00049-005-0309-5

ALDROVANDI U. 1644. De animalibvs insectis libri septem cvm singvlorvm iconibvs ad viuum expressis. Cum indice copiosissimo. Ferronium, Bonon.

Allgaier C. 2014. How can two soft bodied animals be precisely connected? A miniature quick-connect system in the slugs, Arion lusitanicus and Arion rufus. Journal of Morphology 276: 631-648. https://doi.org/10.1002/ jmor.20361

ANDERSON R. 2005. An annotated list of the non-marine Mollusca of Britain and Ireland. Journal of Conchology 38: 607-637.

BACKELJAU T., VAN BEECK M. 1986. Epiphallus anatomy in the Arion hortensis species aggregate (Mollusca, Pulmonata). Zoologica Scripta 15: 61-68. https://doi. org/10.1111/j.1463-6409.1986.tb00209.x

BALASHOV I. 2018. Case 3685 - Arion vulgaris MoquinTandon, 1855 (Gastropoda, Stylommatophora, Arionidae): proposed validation of the specific name as available. Bulletin of Zoological Nomenclature 75: 12-15. https://doi.org/10.21805/bzn.v75.a006

BlATTMANN T., BOCH S., TÜRKE M., KNOP E. 2013 Gastropod seed dispersal: an invasive slug destroys far more seeds in its gut than native gastropods. PLoS ONE 8(9): e75243. https://doi.org/10.1371/journal. pone. 0075243

BOATO A., BODON M., GiUSTI F. 1983. On a new slug from the Northern Apennines (Pulmonata: Arionidae). Archiv für Molluskenkunde 114: 35-44.

BOetTGer C. R. 1949a. Über das Vorkommen einer zweiten Art von großen Wegschnecken (Arion sens. strict.) in Deutschland. Verhandlungen der deutschen Zoologen vom 24.-28. August 1948 in Kiel: 499-501.

Boettger C. R. 1949b. Zur Kenntnis der großen Wegschnecken (Arion s. str.) Deutschlands. Archiv für Molluskenkunde 78: 169-186.
CAin A. J., Williamson M. H. 1958. Variation and specific limits in the Arion ater aggregate. Proceedings of the Malacological Society of London 33: 72-86.

CAstillejo J. 1997. Babosas del Noroeste Ibérico. Universidade de Santiago de Compostela, Servico de Puplicatións e Intercambio Científico, Santiago de Compostela.

CAstillejo J. 1998. Guía de las babosas ibéricas. Real Academia Galega de Ciencias, Santiago.

CAstillejo J., Rodríguez T. 1991. Babosas de la península ibérica y Baleares. Inventario crítico, citas y mapas de distributión. (Gastropoda, Pulmonata, Terrestria nuda). Monografías de la Universidad de Santiago de Compostela 162. Servicio de publicaciones de la Universidad de Santiago de Compostela, Santiago de Compostela.

CASTILlejo J., RodRíguez T. 1993. Las especies del genero Arion Férussac, 1819 en Portugal (Gastropoda, Pulmonata: Arionidae). Graellsia 49: 17-37.

CAstillejo J., RodrígueZ-CASTRo J., Iglesias-PiÑEIRO J. 2019. Estudio comparativo de la anatomía y caracterización del ADN de los ariónidos descritos por Torres Mínguez (1925) en Cantabria (España): Arion cendreroi y A. fulvipes, y la de A. rufus y A. vulgaris (Gastropoda Pulmonata: Arionidae). Spira 7: 49-69.

Chevallier H. 1972. Arionidae (Mollusca, Pulmonata) des Alpes et du Jura francais. Haliotis 2: 7-23.

CHevallier H. 1974. Les grands Arion de France (Mollusca, Pulmonata). Taxonomie, biogeographie, écologie, polymorphisme, croissance et cycle biologique. Ph. D. Thesis, Université de Paris.

Chevallier H. 1981. Taxonomie des "Limaces rouges" (genre Arion, sous-genre Arion s.s., Mollusca, Pulmonata). Haliotis 11: 87-99.

Clement M., Posada D., Crandall K. A. 2000. TCS: a computer program to estimate gene genealogies. Molecular Ecology 9: 1657-1660. https://doi. org/10.1046/j.1365-294x.2000.01020.x

COLLINGE W. E. 1897a. Some observations on certain species of Arion. Journal of Malacology 6: 7-10, Pl. II. https://biodiversitylibrary.org/page/16099983 
COLLINGE W.E. 1897b. On some European slugs of the genus Arion. Proceedings of the Zoological Society of London 3: 439-450. https://doi.org/10.1111/j.1096-3642.1897. tb03102.x

Currat M., Ruedi M., Petit R. J., Exoffier L. 2008. The hidden side of invasions: massive introgression by local genes. Evolution 62: 1908-1920. https://doi. org/10.1111/j.1558-5646.2008.00413.x

DAVIES S. M. 1987. Arion flagellus Collinge and A. lusitanicus Mabille in the British Isles: a morphological, biological and taxonomic investigation. Journal of Conchology 32: 339-354.

Dreijers E., ReISE H., HutChinson J. M. C. 2013. Mating of the slugs Arion lusitanicus auct. non Mabille and $A$ rufus (L.): different genitalia and mating behaviours are incomplete barriers to interspecific sperm exchange. Journal of Molluscan Studies 79: 51-63. https://doi. org/10.1093/mollus/eys033

DVOŘÁK L., HoRSÁK M. 2003. Současné poznatky o plzáku Arion lusitanicus (Mollusca: Pulmonata) v České republice. Časopis Slezského Muzea Opava (A) 52: 67-71.

EHRMANN P. 1933. Kreis: Weichtiere, Mollusca. In: BROHMER P., EHRMANN P., ULMER G. (eds). Die Tierwelt Mitteleuropas. Vol. II (1) Mollusca, Crustacea, Isopoda, Myriapoda. Quelle \& Meyer, Leipzig, pp. 1-264.

ENGELKE S., KÖMPF J., JORDAENS K., TOMIUK J., PARKER E. D. 2011. The genetic dynamics of the rapid and recent colonization of Denmark by Arion lusitanicus (Mollusca, Pulmonata, Arionidae). Genetica 139:709-721. https:// doi.org/10.1007/s10709-011-9565-1

EvANS N. J. 1986. An investigation of the status of the terrestrial slugs Arion ater ater (L.) and Arion ater rufus (L.) (Mollusca, Gastropoda, Pulmonata) in Britain. Zoologica Scripta 15: 313-322. https://doi. org/10.1111/j.1463-6409.1986.tb00232.x

FALKNER G. 1981. Vier bemerkenswerte kulturfolgende Schneckenarten in Hildesheim-Ochtersum. Mitteilungen der zoologischen Gesellschaft Braunau 3: 391-396.

FÉrussaC A. E. J. P. J. F. D’Audebard DE, Deshayes G.P. 1819-1851. Histoire naturelle générale et particulière des mollusques terrestres et fluviatiles, tant des espèces que l'on trouve aujourd'hui vivantes, que des dépouilles fossiles de celles qui n'existent plus; classés d'après les caractères essentiels que présentent ces animaux et leurs coquilles. J.-B. Bailliere, Paris. https:// doi.org/10.5962/bhl.title.132272

FISCHER W., REISCHÜTZ P. L. 1998. Grundsätzliche Bemerkungen zum Schadschneckenproblem. Die Bodenkultur 49: 281-292.

FLEMING J. 1822. Mollusca. In: [NAPIER M. (ed.)] Supplement to the fourth, fifth and sixth editions of the Encyclopædia Britannica with preliminary dissertations on the history of sciences. Vol. 5. Constable, Edinburgh, pp. 567-584.

Folmer O., Black M., HoeH W., LutZ R., VRijenHOeK R. 1994. DNA primers for amplification of mitochondrial cytochrome $c$ oxidase subunit I from diverse metazoan invertebrates. Molecular Marine Biology and Biotechnology 3: 294-299.
FRÖMMING E. 1953. Massenvorkommen von roten Arion rufus L. in Berlin. Archiv für Molluskenkunde 82: 77-78.

GARSAUlT F. A. P. DE 1764. Les figures des plantes et animaux d'usage en medecine, décrits dans la Matiere Medicale de Mr. Geoffroy medecin, dessinés d'après nature par Mr. de Garsault, gravés par Mrs. Defehrt, Prevost, Duflos, Martinet \&c. Niquet scrip. Vol. 5. Paris. https://doi.org/10.5962/bhl.title.49481

GARSAULT F. A. P. DE 1767. Description, vertus et usages de sept cents dix-neuf plantes, tant étrangeres que de nos climats; et de cent trente-quatre animaux, en sept cents trente planches, gravées en taille-douce, sur les desseins d'après nature, de M. de Garsault, par MM. de Fehrt, Prevost, Duflos, Martinet, \&c. Et rangées suivant l'ordre du livre intitulé Matiere Médicale de M. Geoffroy. Ouvrage utile à toutes matieres médicales, aux artistes, aux personnes charitables, \& à tous ceux qui préparent eùx-memes leurs médicaments. Didot, Paris.

GERHARDT U. 1940. Neue biologische Nacktschneckenstudien. Zeitschrift für Morphologie und Ökologie von Tiere 36: 557-580. https://doi.org/10.1007/ BF01260999

GRIMM B. 2001. Life cycle and population density of the pest slug Arion lusitanicus Mabille (Mollusca: Pulmonata) on grassland. Malacologia 43: 25-32. https://biodiversitylibrary.org/page/13142874

HAgnell J., SCHANDER C., VON PROSChWITZ T. 2004. Sniglarna som rör om i trädgårdar och släktträd. Fauna och Flora 99: 38-41.

Hatteland B. A., Roth S., Andersen A., KaAsa K., StøA B., SOLHØY T. 2013. Distribution and spread of the invasive slug Arion vulgaris Moquin-Tandon in Norway. Fauna norvegica 32: 13-26. https://doi.org/10.5324/ fn.v32i0.1473

Hatteland B. A., SOlhøy T., Schander C., SKage M., VON PROSCHWITZ T., NOBLE L. R. 2015. Introgression and differentiation of the invasive slug Arion vulgaris from native A. ater. Malacologia 58: 303-321. https:// doi.org/10.4002/040.058.0210

HESSE P. 1926. Die Nacktschnecken der palaearktischen Region. Abhandlungen des Archivs für Molluskenkunde 2(3): 1-152, Pl. I-II.

HORSÁK M., JUŘIČKOVÁ L., PICKA J. 2013. Molluscs of the Czech and Slovak Republics. Nakladatelství Kabourek, Zlín.

HutChinson J. M. C., REISE H. 2015. Mating in Ariunculus isselii, an arionid slug without a spermatophore. Journal of Molluscan Studies 81: 247-258. https://doi. org/10.1093/mollus/eyu086

HutChinson J. M. C., SCHLITT B., KoŘÍNKOVÁ T., REISE H., BARKER G. M. in submission. Genetic evidence illuminates the origin and global spread of the slug Deroceras invadens.

ICZN 1999. International code of zoological nomenclature. Fourth edition. International Trust for Zoological Nomenclature, London.

JAECKEL S. G. H. 1962. Ergänzungen und Berichtigungen zum rezenten und quartären Vorkommen der mitteleuropäischen Mollusken. In: BROHMER P., EHRMANN 
P., Ulmer G. (eds). Die Tierwelt Mitteleuropas Vol. II (1), Ergänzung. Quelle \& Meyer, Leipzig, pp. 25-294.

Jensen K., ENGELKe S., Simpson S. J., MAYNTZ D., Hunt J. 2013. Balancing of specific nutrients and subsequent growth and body composition in the slug Arion lusitanicus. Physiology \& Behavior 122: 84-92. https://doi. org/10.1016/j.physbeh.2013.08.023

KADOlsky D., Welter-Schultes F., BANK R. A. 2018. Comment (Case 3685) - Arion vulgaris Moquin-Tandon, 1855 (Gastropoda, Stylommatophora, Arionidae): modified proposal to preserve the specific name in its accustomed sense. Bulletin of Zoological Nomenclature 75: 251-254. https://doi.org/10.21805/bzn.v75.a051

KAPPES H., KoBIALKA H. 2009. Die Nacktschneckengesellschaften in NW-Deutschland (Gastropoda: Milacidae, Boettgerillidae, Limacidae, Agriolimacidae, Arionidae): ein Ergebnis der NRW-Kartierung. Natur und Heimat 69: 73-94.

KAPPES H., StOll S., HAASE P. 2012. Differences in field behavior between native gastropods and the fast-spreading invader Arion lusitanicus auct. non Mabille. Belgian Journal of Zoology 142: 49-58.

KERNEY M. 1999. Atlas of the land and freshwater molluscs of Britain and Ireland. Harley Books, Great Horkesley.

Kerney M. P., CAmeron R. A. D., JungBluth J. H. 1983. Die Landschnecken Nord- und Mitteleuropas. Paul Parey, Hamburg.

KNOP E., REUSSER N. 2012. Jack-of-all-trades: phenotypic plasticity facilitates the invasion of an alien slug species. Proceedings of the Royal Society B 279: 4668-4676. https://doi.org/10.1098/rspb.2012.1564

KoZŁOWSKI J. 2007. The distribution, biology, population dynamics and harmfulness of Arion lusitanicus Mabille, 1868 (Gastropoda: Pulmonata: Arionidae) in Poland. Journal of Plant Protection Research 47: 219-230. http://www.plantprotection.pl/pdf-9095025302? filename $=$ The\%20distribution_.pdf

KozŁOWsKi J., KozŁowsKi R. J. 2011. Expansion of the invasive slug species Arion lusitanicus Mabille, 1868 (Gastropoda: Pulmonata: Stylommatophora) and dangers to garden crops - a literature review with some new data. Folia Malacologica 19: 249-258. https://doi. org/10.2478/v10125-011-0005-8

LIKHAREV I. M., WIKTOR A. 1980. Slizni fauny SSSR i sopredel'nykh stran (Gastropoda terrestria nuda). Fauna SSSR: Mollyuski (Novaja serija 122) Tom 3(5). Fauna of the USSR: Mollusca (New series 122) Vol. III, Part 5]. Nauka, Leningrad.

LINNÆUS [LINNAEUS] C. 1746. Fauna Svecica sistens animalia Sveciæ Regni: qvadrupedia, aves, amphibia, pisces, insecta, vermes, distributa per classes \& ordines, genera \& species. Cum differentiis specierum, synonymis autorum, nominibus incolarum, locis habitationum, descriptionibus insectorum. Wishoff, Lugduni Batavorum. https://doi.org/10.5962/bhl.title.34892

LINNÆUS [LINNAEUS] C. 1758. Systema naturæ per regna tria naturæ, secundum classes, ordines, genera, species, cum characteribus, differentiis, synonymis, locis. Tomus I. Editio decima, reformata. Salvius, Holmiæ. https://doi.org/10.5962/bhl.title.542
LINNÉ [LinNAEUS] C. A 1767. Systema naturæ, Tom. I. Pars II. Editio duodecima reformata. Salvius, Holmiæ.

LISTER M. 1678. Historiæ animalium Angliæ tres tractatus. Unus de araneis. Alter de cochleis tum terrestribus tum fluviatilibus. Tertius de cochleis marinis. Quibus adjectus est quartus de lapidis ejusdem insulæ ad cochlearum quandam imaginem figuratis. Memoriæ \& Rationi. Martyn, Londini. https://doi.org/10.5962/bhl. title. 65746

LISTER M. 1685. Appendicis ad historiæ animalium Angliæ, tres tractatus, \&c. Altera editiio, auctior \& emendatior. Smith, Londini.

MACGREgOR A. 2001. The Ashmolean as a museum of natural history, 1683-1860. Journal of the History of Collections 13: 125-144. https://doi.org/10.1093/ jhc/13.2.125

MOQUIN-TANDON A. 1855. Histoire naturelle des mollusques terrestres et fluviatiles de France. Vol. II. and Atlas J.-B. Baillière, Paris. https://doi.org/10.5962/bhl. title. 13098

Muder P., Tietz O., JeChOREK H. 2002. Geologische und bergbaukundliche Exkursion in den Tagebau Berzdorf. In: TIETZ O. (ed.). Sammlung geologischer Exkursionsführer des Staatlichen Museums für Naturkunde Görlitz 1995-2005, pp. 72-83. Unpublished, available at library of the Senckenberg Museum of Natural History Görlitz.

MÜLLER O. F. 1774. Vermivm terrestrium et fluviatilium, seu animalium infusoriorum, helminthicorum, et testaceorum, non marinorum, succincta historia. Volumen alterum. Heineck \& Faber, Havniæ \& Lipsiæ. https:// doi.org/10.5962/bhl.title.46299

Noble L. R. 1992. Differentiation of large arionid slugs (Mollusca, Pulmonata) using ligula morphology. Zoologica Scripta 213: 255-263. https://doi. org/10.1111/j.1463-6409.1992.tb00330.x

NOBLE L. R., JONES C. S. 1996. A molecular and ecological investigation of the large arionid slugs of North-West Europe: the potential for new pests. In: SYMONDSON, W. O. C., LIDDEL, J. E. (eds). The ecology of agricultural pests: biochemical approaches. The Systematics Association special volume series 53. Chapman \& Hall, London, pp. 93-131.

ODHNER N. H. 1951. Swedish high mountain Mollusca. In: BRINK P., WINGSTRAND K. G. (eds). The mountain fauna of the Virihaure area in Swedish Lapland. C.W.K. Gleerup, Lund, pp. 26-50.

PĂPUREANU A.-M., REISE H., VARGA A. 2014. First records of the invasive slug Arion lusitanicus auct. non Mabille (Gastropoda: Pulmonata: Arionidae) in Romania. Malacologica Bohemoslovaca 13: 6-11. http://mollusca. sav.sk/pdf/13/13.Papureanu.pdf

PARADIS E., JOMBART T., BRIAN K., SCHLIEP K., POTTS A., WinTER D., Kamvar Z. N. 2018. Population and evolutionary genetics analysis system v. 0.11. http:// ape-package.ird.fr/pegas.html accessed 17.viii.2019.

PARMAKELIS A., KOTSAKIOZI P., RAND D. 2013. Animal mitochondria, positive selection and cyto-nuclear coevolution: insights from pulmonates. PLoS ONE 8: e61970. https://doi.org/10.1371/journal.pone.0061970 
Peláez M., Valdecasas A. G., Martinez D., Horreo J. L. 2018. Towards the unravelling of the slug $A$. ater- $A$. rufus complex (Gastropoda Arionidae): new genetic approaches. Web Ecology 18: 115-119. https://doi. org/10.5194/we-18-115-2018

PfENNINGER M., WeIgAND A., BÁLINT M., KLUSSMANNKolB A. 2014. Misperceived invasion: the Lusitanian slug (Arion lusitanicus auct. non-Mabille or Arion vulgaris Moquin-Tandon 1855) is native to Central Europe. Evolutionary Applications 7: 702-713. https://doi. org/10.1111/eva.12177

PilsBry H. A. 1948. Land Mollusca of North America (north of Mexico). Volume II, Part 2. Academy of Natural Sciences of Philadelphia, Monographs 3.

POLlONERA C. 1890: Recensement des Arionidae de la région Paléarctique. Bollettino dei Musei di Zoologia ed Anatomia Comparata della Reale Università di Torino 5(87): 1-42.

Proschwitz T. VON 1985. Röda skogssnigeln Arion rufus (L.), en mellaneuropeisk art stadd i snabb spridning med människan i Sverige. Fauna och Flora 80: 121-138.

PROSCHWITZ T. VON 1996. Utbredning och spridning av spansk skogssnigel [Arion lusitanicus Mabille] och röd skogssnigel [Arion rufus (L.)] - En översikt av utvecklingen i Sverige. Göteborgs Naturhistoriska Museum, Årstryck, 1996: 27-45.

Proschwitz T. VON 1997. Arion lusitanicus Mabille and A. rufus (L.) in Sweden: A comparison of occurrence, spread and naturalization of two alien slug species. Heldia 4: 137-138.

QUICK H. E. 1947. Arion ater (L.) and A. rufus (L.) in Britain and their specific differences. Journal of Conchology 22: $249-261$.

QUICK H. E. 1952. Rediscovery of Arion lusitanicus Mabille in Britain. Proceedings of the Malacological Society of London 29: 93-101.

QUICK H. E. 1960. British slugs (Pulmonata; Testacellidae. Arionidae, Limacidae). Bulletin of the British Museum (Natural History), Zoology 6: 105-226. https://doi. org/10.5962/bhl.part.26845

QUiNTEIRO J., RODRÍGUEZ-CASTRO J., CASTILlEJO J., IGLESIAS-PIÑEIRO J., REY-MÉNDEZ M. 2005. Phylogeny of slug species of the genus Arion: evidence of monophyly of Iberian endemics and of the existence of relict species in Pyrenean refuges. Journal of Zoological Systematics and Evolutionary Research 43: 139-148. https://doi.org/10.1111/j.1439-0469.2005.00307.x

RABITSCH W. 2006. DAISIE - Arion vulgaris (Moquin-Tandon, 1855) Fact Sheet. - Online Database of Delivering Alien Invasive Species Inventories for Europe. http://www. europe-aliens.org accessed 14.viii.2019.

REISCHÜTZ P. L. 1984. Zum massenhaften Auftreten von Arion lusitanicus Mabille in den Jahren 1982 und 1983. Mitteilungen der zoologischen Gesellschaft Braunau 4: 253-254.

REISCHÜTZ P. L., SEIDL F. 1982. Gefährdungsstufen der Mollusken Österreichs. Mitteilungen der zoologischen Gesellschaft Braunau 4: 117-128.
REISE H. 2013. Wie seziert man Nacktschnecken? Mitteilungen der deutschen malakozoologischen Gesellschaft 88: 29-32. http://www.dmg.mollusca. de/images/mitteilungen dmg/mitteilungen088/mitt dmg_088_029-032_reise.pdf

REISE H., BACKelJAU T., SEIDEL D. 1996. Erstnachweise dreier Schneckenarten und weitere malakofaunistisch bemerkenswerte Funde aus der Oberlausitz. Berichte der naturforschenden Gesellschaft der Oberlausitz 5: 39-47. https://naturforschende-gesellschaft-der-oberlausitz. de/sites/default/files/pdf/bd05_03_reise-backeljauseidel_schnecken.pdf

ReISE H., SCHLITT B., HutChinson J. M. C. 2018a. Bericht über die 33. Regionaltagung des Arbeitskreises Ost der DMG in Ostritz bei Görlitz vom 23. bis 25. September 2016: Mollusken des Rotsteins bei Sohland, Sachsen. Mitteilungen der deutschen malakozoologischen Gesellschaft 98: 35-44. http://www.dmg.mollusca. de/images/mitteilungen_dmg/mitteilungen098/mitt dmg_098_035-044_reise.pdf

REISE H., ARSLANGÜNDOĞDU Z., SCHLITT B., HUTCHINSON J. M. C., HizAl E., BACACK E. 2018b. First records of the terrestrial slug Arion ater s.l. (Linnaeus, 1758) (Pulmonata: Arionidae) from Turkey. Folia Malacologica 26: 213-220. https://doi.org/10.12657/folmal.026.024

REgTEREN ALTENA C. O. VAN 1956. Notes sur les Limaces. 3. Sur la présence en France d' Arion lusitanicus Mabille. Journal de Conchyliologie 45: 89-99.

REGTEREN ALtenA C. O. VAN 1963. Notes sur les limaces. 8. Sur l'état de deux espèces nominales du genre Arion. Basteria 27: 1-6. http://natuurtijdschriften.nl/ download? type $=$ document $\&$ docid $=596445$

RHYMER J. M., SIMBERLOFF D. 1996. Extinction by hybridization and introgression. Annual Review of Ecology and Systematics 27: 83-109. https://doi.org/10.1146/ annurev.ecolsys.27.1.83

RISCH P., BACKELJAU T. 1989. On the occurrence of Arion lusitanicus Mabille, 1868 in Belgium (Mollusca: Pulmonata). Annales de la Société royale zoologique de Belgique 118: 25-38.

Roth S., HATTELAND B. A., SOLHøY T. 2012. Some notes on reproductive biology and mating behaviour of Arion vulgaris Moquin-Tandon 1855 in Norway including a mating experiment with a hybrid of Arion rufus (Linnaeus 1758) $\mathrm{x}$ ater (Linnaeus 1758). Journal of Conchology 41: 249-257.

Rowson B., ANDERson R., Turner J. A., SyMONDSON W. O. C. 2014a. The slugs of Britain and Ireland: undetected and undescribed species increase a well-studied, economically important fauna by more than $20 \%$. PLoS ONE 9(3): e91907. https://doi.org/10.1371/journal. pone.0091907

ROWSON B., TURNER J. A., ANDERSON R., SYMONDSON W. O. C. 2014b. Slugs of Britain and Ireland. FSC Publications, Telford.

RÜETSCHI J., STUCKI P., MÜLLER P., VICENTINI H., ClAUdE F. 2012. Rote Liste Weichtiere (Schnecken und Muscheln). Gefährdete Arten der Schweiz, Stand 2010. Bundesamt für Umwelt, Bern und Schweizer Zentrum für die Kartographie der Fauna, Neuenburg. Umwelt- 
Vollzug Nr. 1216. https://www.bafu.admin.ch/bafu/de/ home/themen/biodiversitaet/publikationen-studien/ publikationen/rote-liste-weichtiere.html

RYSER S., RINDLISBACHER N., GRÜEBLER M. U., KNOP E. 2011. Differential survival rates in a declining and an invasive farmland gastropod species. Agriculture, Ecosystems \& Environment 144: 302-307. https://doi. org/10.1016/j.agee.2011.08.005

SCHILEYKO A. A. 2007. Treatise on recent terrestrial pulmonate molluscs. Part 15: Oopeltidae, Anadenidaje, Arionidae, Philomycidae, Succineidae, Athoracophoridae. Ruthenica, Suppl. 2: 2049-2210.

SCHMID G. 1972. Nacktschnecken aus Baden-Württemberg. Mitteilungen der deutschen malakozoologischen Gesellschaft 2: 332-344.

SCHMID G. 1997. "Malakologische Zuckungen" Momentaufnahmen zur Molluskenfauna BadenWürttembergs. Veröffentlichungen für Naturschutz und Landschaftspflege in Baden-Württemberg 71/72: 719-858.

SeIFERT B., KUlmuni J., PAMilO P. 2010. Independent hybrid populations of Formica polyctena $X$ rufa wood ants (Hymenoptera: Formicidae) abound under conditions of forest fragmentation. Evolutionary Ecology 24: 1219-1237. https://doi.org/10.1007/s10682-0109371-8

Simon C., Frati F., BeCKenbach A., Crespi B., LiU H., FLOOK P. 1994. Evolution, weighting, and phylogenetic utility of mitochondrial gene sequences and a compilation of conserved polymerase chain reaction primers. Annals of the Entomological Society of America 87: 651-701. https://doi.org/10.1093/aesa/87.6.651

SimRoTH H. 1885. Versuch einer Naturgeschichte der deutschen Nacktschnecken und ihrer europäischen Verwandten. Zeitschrift für wissenschaftliche Zoologie 42: 203-366, Pl. VII-XI. https://biodiversitylibrary.org/ page/ 45468576

Slotsbo S., Fisker K. V., HANSEN L. M., HolmStrup M. 2011b. Drought tolerance in eggs and juveniles of the Iberian slug, Arion lusitanicus. Journal of Comparative Physiology B 181: 1001-1009. https://doi.org/10.1007/ s00360-011-0594-y

Slotsbo S., HANSEN L. M., Holmstrup M. 2011a. Low temperature survival in different life stages of the Iberian slug, Arion lusitanicus. Cryobiology 62: 68-73. https://doi.org/10.1016/j.cryobiol.2010.12.005

Slotsbo S., HANSEN L. M., JORDAENS K., BACKELJAU T., Malmendal A., Nielsen N. C., Holmstrup M. 2012. Cold tolerance and freeze-induced glucose accumulation in three terrestrial slugs. Comparative Biochemistry and Physiology Part A: Molecular \& Integrative Physiology 161: 443-449. https://doi. org/10.1016/j.cbpa.2012.01.002

SMITH A. H. 1961. The place-names of the West Riding of Yorkshire. Part II. Osgoldcross and Agbrigg Wapentakes. English Place-Name Society, Vol. XXXI. Cambridge University Press, Cambridge.
TAYLOR J. W. 1902-1907. Monograph of the land and freshwater Mollusca of the British Isles. Testacellidae, Limacidae, Arionidae. Taylor Brothers, Leeds.

TAYLOR J. E. 1975. "Ambry". In: Historic Almondbury: the village on the hill. Kirklees Libraries and Museum Service, pp. 7-10.

Welter-Schultes F. W., Klug R., Lutze A. 2008. Les figures des plantes et animaux d'usage en medecine, a rare work published by F. A. P. de Garsault in 1764 . Archives of Natural History 35: 118-127. https://doi. org/10.3366/E0260954108000119

WIKTOR A. 1973. Die Nacktschnecken Polens - Arionidae, Milacidae, Limacidae (Gastropoda, Stylommatophora). Monografie Fauny Polski, Vol. 1. Państwowe Wydawnictwo Naukowe, Warszawa.

WIKTOR A. 2004. Ślimaki lądowe Polski. Wydawnictwo Mantis, Olsztyn.

WINTER A. J. DE 1984. The Arion hortensis complex (Pulmonata: Arionidae): designation of types, descriptions, and distributional patterns, with special reference to the Netherlands. Zoologische Mededelingen. 59: 1-17. https://www.repository.naturalis.nl/document/150316

WINTER A. J. DE 1989. Arion lusitanicus Mabille in Nederland (Gastropoda, Pulmonata, Arionidae). Basteria 53: 4951.

Zemanova M. A., Broennimann O., Guisan A., KNOP E., HECKEL G. 2018. Slimy invasion: climatic niche and current and future biogeography of Arion slug invaders. Diversity and Distributions 2018: 1-14. https://doi. org/10.1111/ddi.12789

Zemanova M. A., KNOP E., HeCKEl G. 2015. Development and characterization of novel microsatellite markers for Arion slug species. Conservation Genetic Resources 7: 501-503. https://doi.org/10.1007/s12686-014-0406-2

Zemanova M. A., Knop E., Heckel G. 2016. Phylogeographic past and invasive presence of Arion pest slugs in Europe. Molecular Ecology 25: 5747-5764. https:// doi.org/10.1111/mec.13860

Zemanova M. A., KNOP E., HeCKel G. 2017. Introgressive replacement of natives by invading Arion pest slugs. Scientific Reports 7: 41908. https://doi.org/10.1038/ s41598-017-14619-y

Zettler M. L., Jueg U., MenZel-HarlofF H., GÖLlnitZ U., Petrick S., Weber E., Seemann R. 2006. Die Landund Süßwassermollusken Mecklenburg-Vorpommerns. Obotritendruck, Schwerin.

ZILCH A. 1962. Ergänzungen und Berichtigungen zur Nomenklatur und Systematik. In: BROHMER P., EHRMANN P., Ulmer G. (eds). Die Tierwelt Mitteleuropas Vol. II (1), Ergänzung. Quelle \& Meyer, Leipzig, pp. $1-23$.

Received: October 3rd, 2019

Revised: January 16th, 2020

Accepted: January 19th, 2020

Published on-line: March 13th, 2020 